\title{
Corporate Governance and Firm Performance in Emerging Markets: Evidence from India
}

\author{
Sheeba Kapil1', Rakesh Mishra ${ }^{2}$ \\ ${ }^{1}$ Department of Finance, Indian Institute of Foreign Trade, New Delhi, India \\ ${ }^{2}$ Indian Institute of Foreign Trade, New Delhi, India \\ Email: sheebakapil@iift.edu,mishrarakeshk@indianoil.in
}

How to cite this paper: Kapil, S. and Mishra, R. (2019) Corporate Governance and Firm Performance in Emerging Markets: Evidence from India. Theoretical Economics Letters, 9, 2033-2069. https://doi.org/10.4236/tel.2019.96129

Received: July 8, 2019

Accepted: August 26, 2019

Published: August 29, 2019

Copyright () 2019 by author(s) and Scientific Research Publishing Inc. This work is licensed under the Creative Commons Attribution International License (CC BY 4.0).

http://creativecommons.org/licenses/by/4.0/

(c) (i) Open Access

\begin{abstract}
This study attempts to explore the link between corporate governance system developed by firms like promoter ownership, institutional relationship (as percentage ownership in the firm), foreign institutional investors (FII) ownership, board size (log assets), family control which is a significant indicator for board independence. Further we have also taken CEO duality, number of board meetings and busyness of directors and linked it with firm performance. Market based firm performance measures and accounting based performance show different impact. Findings indicate that impact of corporate governance variables on market based performance measures (Tobin's $Q$ ) is greater than the impact on accounting based performance measures (ROA and ROE). Ownership structure i.e. family capitalism impacts market based performance measures more whereas board structure impacts accounting based performance measure more. Among board variables, board size is found to impact performance positively and CEO duality is found to impact performance negatively. Board independence i.e. "monitoring board" is found to impact accounting based performance positively, whereas number of board meetings is found to impact market based performance measure positively. Directors' internal busyness is not found to impact any of the performance measures. Directors' external busyness is impacting accounting based measures negatively when the busyness is measured in terms of position of directors in other companies.
\end{abstract}

\section{Keywords}

Corporate Governance, Ownership Structure, Board Structure, Firm Performance, India, Emerging Markets, Family Capitalism

\section{Introduction}

In this study, we study the impact of internal corporate governance-CG me- 
chanisms on firm performance in emerging markets where increasingly corporate governance is compromised. Recently, companies like Yes Bank, ICICI Bank, P C Jewelers, Fortis Hospital, etc. lost their share price value due to bad governance practice news. In Yes Bank and Axis Bank case, the Reserve Bank of India (India's central bank) had refused to extend the tenure of their CEOs. ICICI Bank opened investigations against its CEO Ms Chanda Kochar who was removed and investigated on charges of nepotism and conflict of interest. Infosys Ltd known for good corporate governance was charged with accusation that the board was allying with the founder-promoters rather than worrying about shareholders. Smaller companies like PC Jewelers and Infibeam also came under light for making opaque deals and group transactions with limited disclosure. The common thread between these events is "Weak Corporate Governance". The study tests the theories developed in developed economies or are context specific that how corporate governance mechanisms affect the firm performance.

Corporations pool capital from a large investor base both in the domestic and international capital markets. When an investor invests money in a corporation, she expects the board and the management, to act as trustees of this money and ensure the safety of the capital and also earn a rate of return that is higher than the cost of capital. In this regard, corporate governance provides framework for the "ways in which suppliers of finance to corporations assure themselves of getting a return on their investment" (Shleifer and Vishny [1]; Becht et al. [2]). Board of directors is expected to adopt good corporate governance mechanism for ensuring that managers act in the interests of shareholders. Corporate governance deals with constraints that managers put on themselves, or that investors put on managers, to reduce the ex post misallocation and thus to induce investors to provide more funds ex ante (Shleifer and Vishny [1]). However, scandals happened in cases of ABB, Banesto, Dynergy, Enron, Global Crossing, Metallgesellschaft, Qwest, Satyam, Seat, Suez, Swissair, Tyco, Vivendi and WorldCom during late 1990s and early 2000s, indicate that corporate governance mechanism couldn't serve its intended purpose. Many countries undertook wide ranging corporate governance reforms in a reaction to these corporate failures. These reforms have typically followed public disquiet about incidents of actual or perceived corporate excess and an assessment that various market failures might necessitate intervention (Girma et al. [3]). The essence of these reforms were to support and protect investors from the agents, or in other words to reduce agency costs therein. Another motive that guided these reforms was to arrange low cost capital, which was validated by studies (e.g. Chalevas and Tzovas [4]) establishing that the adoption of mandatory corporate governance mechanisms decreased firms' weighted average cost of capital and increased firm's financing.

In the last two decades, extensive empirical research on corporate governance took place in the context of developed economies (e.g. Hermalin and Weishbach 
[5]; Kang and Shivdasani [6]; Judge et al. [7]; Gompers et al. [8]; Pass [9]; Bauer et al. [10]; Bhagat and Bolton [11]). Developing economies also witnessed empirical researches in corporate governance with their emergence. There are important organizational and behavioural differences between firms in emerging markets and those in developed markets. Governance quality, state ownership and financial development are critical institutional forces that shape the financing and governance of firms in emerging markets (Fan et al. [12]). These institutional differences indicate that relationships obtained through data from developed economies may not be fully applicable to developing economies.

Corporate governance mechanisms have been found to be correlated with firm performance in various theoretical and empirical studies done in the context of emerging economies (Khanna and Palepu [13] [14]; Gibson [15]; Klapper and Love [16]; Young et al. [17]; Ehikioya [18]; Claessens and Yurtoglu [19]). Well-functioning corporate governance mechanisms in emerging economies are of crucial importance for both local firms and foreign investors which are interested in pursuing the tremendous opportunities for investment and growth that such emerging economies provide (Rajagopalan and Zhang [20]). From the perspective of local firms, evidences suggest that firms in emerging economies (compared with their counterparts in developed countries) are discounted in financial markets because of their weak governance (LaPorta et al. [21]). Improvements in corporate governance can enhance investor confidence for firms in emerging economies and increase these firms' access to capital (Rajagopalan and Zhang [20]).

The paper is organized as follows. In the next section, we review theoretical arguments as well as prior empirical evidence on relationship between corporate governance variables and firm performance and put forward our arguments for hypotheses development. This is followed by description of model, variables and their measures employed. After that, we present data descriptive followed by results and analysis. Finally, we conclude with discussion and point out future directions of study.

\section{Corporate Governance in India}

The Indian government initiated market reforms in 1991, which resulted in opening of the Indian economy to multinational and foreign investment. Increased foreign investment in India intensified the interest in good corporate governance and in particular the application of western governance structure to Indian firms (Jackling and Johl [21]). India needed capital to finance the expansion of market spaces created by liberalization and outsourcing opportunities. Amongst other things this need of capital led to corporate governance reforms and major initiatives in this direction. The initial step in this direction was introduction of clause 49 in the listing agreement by Securities and Exchange Board of India (SEBI) which contained prominence of independent directors amongst other provisions. Government of India took a major step in this direction by making provisions of 
corporate governance mandatory for Indian companies by introducing Companies Act 2013 (effective from $1^{\text {st }}$ April' 2014).

Major corporate governance issue in India is protecting the interest of minority shareholder(s) through disciplining dominant shareholder(s), unlike Anglo Saxon economies where the central governance issue is disciplining management, who may stop being accountable to the owners (dispersed shareholders). Indian firms are predominantly of the family origin and promoter controlled (Varma [22]; Chakrabarti et al. [23]). Besides family ownership, other forms of domination, such as domination by government or a foreign group, also exist in Indian organizations. Additionally, promoters of companies often exercise influence that is disproportionate to their actual shareholding in the firm (Pande and Ansari [24]).

In family owned corporations that widely prevail in emerging economies (like India), boards are typically dominated by family members who enjoy substantial ownership and control over the corporation and who often hold top executive positions with an objective of controlling the firm (Carney and Gadajlovic [25]). As an implication of the same, board members of family-controlled firms, in their role as monitors may not be that much efficient and may give benefit of doubt to incumbent mangers for low firm performance (Gomez-Mejia et al. [26]). In case of Indian firms, families (founders) are present on the boards in 63.2 (65.5) percent and on an average, founders own over $50 \%$ of outstanding shares (Jameson et al., 2014).

To overcome problems of corporate governance, different internal or external mechanisms can be applied (Dennis and McConnell [27]). Primary internal mechanisms are the equity ownership structure of the firm and board of directors, whereas primary external mechanisms are the legal system and the external market for corporate control (the takeover market). External and internal governance mechanisms are complementary to each other i.e. countries where market for corporate control are not that much prevalent and enforcement of corporate government regulations through legal system are weak, provides a strong case for internal governance mechanisms to be at the forefront for improving corporate performance. Hence, considering the development stage of Indian economy where market for corporate control is still developing (Khanna and Palepu [14]) and there exists a weak legal enforcement regime of corporate governance (Sarkar and Sarkar [28]), it appears that internal governance mechanisms will have significant bearing on corporate performance.

Most of the existing researches in Indian context have focused on identifying the impact of various aspects of corporate governance on Tobin's $Q$ as a measure of firm performance (Kumar [29]; Dharmapala and Khanna [30]; Balasubramian et al. [31]; Kota and Tomar [32]; Kumar and Singh [33]). Most of these researches are based on a single factor (or a few factors) of corporate governance like ownership structure (Varma [22]; Sarkar and Sarkar [28]; Kumar [29]; Chakrabarti et al. [23]), board of governors (Balasubramanian et al. [31]; Kota and 
Tomar [32]), duality of CEO (Kota and Tomar [32]), Disclosure (Pahuja and Bhatia [34]), Audit committee (Kota and Tomar [32]) etc. Yet another set of Indian studies are based on a particular sector or specific firm size and hence have a limited scope of applicability. Few other studies were found to be focused on either public sector or private sector. Present study proposes to be a comprehensive one, correlating corporate governance variables with overall firm performance for Indian companies.

\section{Theoretical Background and Hypotheses}

Firm performance may be improved by reducing agency problems through ownership concentration. Increased ownership stake increases incentive for block holders to monitor managerial behaviour (Shliefer and Vishny [1]), because on the one hand it reduces the problem of free-rider associated with dispersed shareholding (Hart [35]; Burkart et al. [36]) and on the other hand large block holders can take effective concerted action against managerial misbehaviour. However, the relationship between increased stake for block holders and firm performance is not always monotonically increasing, because after becoming too strong block holders may try to extract benefits more than their proportionate share that includes private benefits of control also (Holderness [37]). Thus, value creation through ownership concentration will be a tradeoff between increased shared benefits created and private extraction of values (Mishra and Kapil [38]).

Increase in value of firm and reduction in agency cost may also be achieved through higher managerial ownership as it creates alignment of interests between managers and shareholders (Morck et al. [39]). However, in the situation of greater managerial ownership, managers may act in discretion for utilisation of the surplus generated and may take steps to prolong their stay in the firm (even if it is not justified from value creation perspective termed as managerial entrenchment by Shleifer and Vishny [40]) because of disproportionate power available to them. Thus, the value creation through increased managerial ownership will be a trade-off between entrenchment effect and alignment effect (Mishra and Kapil [38]).

Promoter(s) in general is (are) person(s) who are involved in incorporation and organization of a corporation. Promoters are an important part of companies in Indian context, as most of the companies are of family origin. In India, promoter ownership is also related with promoter control (Kumar and Singh [41]). Certain studies highlighted that often, promoters find themselves making strong representation in the board (Ganguli [42]). When promoters have substantial representation on board as members the board has more close control over the management. Thus promoter and managerial control becomes synonymous with each other. And more close control is exercised over the management. If promoters are majority shareholder and are also in the management, then their interests would be aligned towards overall firm performance indicat- 
ing a positive relationship between promoter ownership and firm performance. However, if their stakes are beyond a threshold level, where they would be in a position to exploit minority shareholders, then, there would be a decrease in firm value (Richter and Chakraborty [43]; Ohadi et al. [44]; Sahu [45]; Kakani et al. [46]). Because of being majority control owner managers may prolong their stay in the firm even if it is not desired from technical/managerial point of view (Anderson and Reeb [47]; Morck et al. [39]).

Among theoretical studies there is no consistency between the direction of relationship between insider ownership and corporate performance. Convergent of interest hypothesis (Jensen and Meckling [48]; McConnell and Servaes [49]; Oswald and Jahera [50]; Hudson et al. [51]; Chung and Pruitt [52]; Chang [53]) says that with increased stake of insiders, the interest of insiders would converge with value creation for company. On the other hand, conflict of interest hypothesis (Jensen and Ruback [54]; Fan and Wong [55]) says that with increased stake, insiders would be in a position to extract benefits more than their proportional share. In some of the studies, relationship between corporate performance and insider ownership has been found non-linear (Morck et al. [39]) or of inverted U-shaped (McConnell and Servaes [49]; Barnhart and Rosenstein [56]; Chen et al. [57]).

\subsection{Based on Above Discussion We Propose Following Hypothesis}

\section{H1: Positive linkage between ownership concentration and firm perfor- mance}

Three different hypotheses propounded by different researchers affect institutional ownership and firm performance relationship: first, efficient monitoring hypothesis (McConnell and Servaes [49]) says that because of their expertise, institutional investors are in a better position to monitor the behaviour of managers which leads to a positive relationship between institutional ownership and firm performance. Second, investment horizon of institutional investors is short as compared to promoters or any other group of shareholders, so value creation time horizon also varies accordingly. This leads to conflict of interest hypothesis (Jensen and Ruback [54]; Barnhart and Rosenstein [56]; Fan and Wong [55]), which predicts negative relationship between institutional ownership and firm performance. Third, stakeholders other than institutional investors do strategic investments which may have long gestation period for generating value whereas institutional investors invest for short term gains which leads to strategic-alignment hypothesis (Pound [58]; Barnhart and Rosenstein [56]) indicating a negative relationship between institutional ownership and firm performance. Institutional ownership firm performance relationship is dependent on the intensity of monitoring role performed by the institution under consideration. Different institutional investors may behave differently in their relationship with corporate performance (Shin-Ping and Tsung-Hsien [59]).

In developing economies like India, where the external mechanisms of corpo- 
rate governance are still not in a fully developed/empowered state and legal resolution to corporate governance issues is not that much effective in comparison to developed economies, the aspect of monitoring the behaviour of managers becomes more important. This leads to following hypothesis:

H2: Institutional ownership has positive relationship with firm performance

Firms belonging to developing economies like India, having significant foreign institutional investor (FII) ownership have shown improved performance in comparison to their peers (Douma et al. [60]). This is due to application of developed country standards of corporate governance, mandated by the investors that own private equity funds. These funds are primarily owned by investors from developed countries. Strategies through which these occur are: reconstituting the board of directors, influencing senior executive recruitment, and changing a firm's operating and strategic rules (Dossani [61]). Hence:

H3: Positive linkage between share of foreign ownership and firm performance

Empirical studies pertaining to the board, address certain specific variables like size of the board, ratio of outside directors and inside directors, CEO duality etc. and their impact on performance of the firm (Hermalin and Weisbach [62]; Shukeri et al. [63]; Fauzi and Locke [64]). The relationship between corporate performance and board size is impacted by two competing aspects; first, slow decision making process under large board and second, a large board providing more linkages to resources and stakeholders (in external environment) and wide experience. Some of the empirical studies indicate positive relation between board size and profitability (Abor and Biekpe [65]); and between board size and return on assets, earnings per share, and market-to-book ratio (Sheikh et al. [66]), whereas others indicated non-linear relationship between board size and earnings management (Alves [67]). Studies in Indian context found small board more effective in enhancing firm value (Kota and Tomar [32]) and indicated a negative relationship between board size and firm value (Kumar and Singh, [41]).

Indian Companies Act 2013 [clause 149(1) of Chapter XI] says that every company shall have a Board of Directors consisting of individuals as directors and shall have-1) a minimum number of three directors in the case of a public company, two directors in the case of a private company, and one director in the case of a One Person Company; and 2) a maximum of fifteen directors. A company may appoint more than fifteen directors after passing a special resolution. The act also stipulates that such class or classes of companies as may be prescribed shall have at least one woman director and every company shall have at least one director who has stayed in India for a total period of not less than one hundred and eighty-two days in the previous calendar year.

There is an inverse relationship between board size and firm performance measured by Tobin's Q (Yermack [68]; Eisenberg et al. [69]), because of lack of 
coordination and communication associated with a large board. It becomes more difficult for all directors to express their ideas and opinions in limited time available when a board has more than 10 members (Lipton and Lorsch [70]). On the other hand, small boards augment monitoring capabilities (Yermack [68]; Khanchel [71]) and are more efficient (Garg [72]). Hence:

H4: There is a negative linkage between Board size and firm performance

Impact of board composition on corporate performance is a tradeoff between two opposing aspects; as per agency theorists more number of internal directors is better for corporate performance because of alignment of interests, whereas more number of outside directors will facilitate in better monitoring and evaluation. As per Indian Companies Act 2013 [Clause 149(4) of Chapter XI], every listed public company shall have at least one-third of the total number of directors as independent directors. However, this minimum number of directors can also be prescribed by the Central Government. Every company existing on or before the date of commencement of this Act ( $1^{\text {st }}$ April 2014) was to comply with the requirements of the provisions, within one year from the date of commencement. Companies Act 2013 [Clause 149(6) of Chapter XI] also says: an independent director in relation to a company, means a director other than a managing director or a whole-time director or a nominee director,-meeting with some other criteria specified therein including he/she must not be related to promoters or directors in the company, its holding, subsidiary or associate company; and has or had no pecuniary relationship with the company, its holding, subsidiary or associate company, or their promoters, or directors, during the two immediately preceding financial years or during the current financial year.

Independent directors are invited on the board to oversee management on behalf of shareholders and their higher proportion on the board may lead to superior financial performance (Baysinger and Butler [73]) and greater firm value (Mak and Kusandi [74]). Outside directors were found to be impacting firm value positively (Black and Kim [75]). However, many studies have found that the proportion of independent directors or grey directors has no significant impact on form performance (Ehikioya [18]; Yammeesri and Herath [76]; Gill [77]). On the contrary some studies (e.g. Sheikh et al. [66]) indicate that outside directors are negatively related to firm performance measures like return on assets, earnings per share, and market-to-book ratio.

However, considering the significant development taken place in India in the form of empowering the board through introduction of clause 49 of listing agreement in which amongst other things independence of board has been emphasized, we propose following hypothesis:

H5: There is positive linkage between board independence and firm performance

Board of directors discharges its responsibilities of monitoring and providing resource linkage through active participation of directors in the board meetings. So, effectiveness of board is dependent on behaviour of board of directors in 
board meetings. Active directors' behavior, i.e. challenging, questioning, informing, encouraging etc.-is an important driver of board effectiveness (Roberts et al. [78]). Board members' commitment, are far more important than board demographics for predicting board task performance (Minichilli et al. [79]). The commitment of the board members will depend upon their involvement in the meeting which refers to their effort during discussions and in the follow-up of the decisions taken during the board meetings (Judge and Zeithaml [80]). Involvement also includes board members' willingness and ability to advance useful questions and to intervene constructively in the board decision making process. Additionally, for making their involvement the board members' must be prepared for the board meeting which refers to their willingness and ability to participate in board meetings with a deep knowledge of the topics to be discussed in order to actively contribute to the decision making process. Hence, number of board meetings and effective participation of board of directors in those meetings are expected to impact firm performance positively.

Board of directors achieve monitoring through board meetings, hence number of board meetings is a good proxy for the monitoring effects of directors (Vafeas [81]). Vafeas [81] demonstrated that boards meet more often during periods of turmoil, and that boards meeting more often show improved financial performance. A board that meets more often should be able to devote more time to issues such as earnings management. A board that seldom meets may not focus on these issues and may perhaps only rubber-stamp management plans. Lipton and Lorsch [70] suggested that the greater frequency of meetings is likely to result in superior performance. Hence, above leads to following hypothesis:

\section{H6: Positive linkage between board meeting and firm performance}

There are two contrasting theoretical arguments regarding impact of board leadership structure on firm performance. Steward theorists advocate managers as good stewards of company resources (Davis et al. [82]), accordingly there is no perceived conflict of interest between shareholders and the managers. Hence, combining the roles of $\mathrm{CEO}$ and chairperson of the board into a single person i.e. $\mathrm{CEO}$ duality is expected to provide strong leadership and unified strategic direction to the firm that may lead into better performance.

However, as per agency theorists responsibility of CEO is to execute the company policies and to run the company where as the responsibility of the chairperson of the board is to monitor and evaluate managerial activities (Lam and Lee [83]). The board is also responsible for the process of hiring, firing, evaluating and compensating the CEO. Hence, separating the two roles "avoids concentration of authority and power in one individual and differentiates leadership of the board from running of the business" (Higgs [84]). It is further argued that CEO duality will lead to domination of board by that person, making the board ineffective in monitoring managerial opportunism (Jensen [85]) and the chairperson should preferably not be the same person (i.e. CEO) whose performance is being assessed (Jensen [85]). CEO duality provides much 
power to CEOs because of which they may further their own interests rather than the interests of shareholders and it may lead to inferior performance (Weisbach [86]).

CEO duality has been found to have significant positive impact on profitability (Abor and Biekpe [85]) and is found to be positively related to earnings per share (Sheikh et al. [66]; Hassan and Halbouni [87]). On the contrary, some studies have also been found that CEO duality impacts firm performance adversely (Ehikioya [18]). CEO duality lead to higher incidence disclosure, suggesting increased scrutiny works (Collett and Dedman [88]). This may lower market valuation and increase cost. Considering the Indian corporate scene with dominance of promoters and business groups having family/related CEOs possessing disproportionate power in the board, we arrive at our next hypothesis:

\section{H7: Negative linkages between CEO duality and firm performance}

Monitoring function as well as resource providing function of board would be established through board meetings. As indicated in various prior studies (Jackling and Johl [21]; Minichilli et al. [79]; Forbes and Milliken [89] etc.) number of times the meeting happens and the "quality of meetings", would decide the effectiveness of the board and subsequently firm performance. When the directors attend at least 75 percent of the meetings, it leads to enhanced firm valuation (Brown and Caylor [90]). Board activity has been found to positively impact firm value (Brick and Chidambaran [91]). In this study internal busyness of directors has been measured in terms of average participation of directors in board meetings which is in line with earlier studies done in the Indian context (Mishra and Mohanty [92]). This leads to our next hypothesis.

H8: Positive linkage between directors internal busyness and firm performance

Number of directorship/chairmanship or committee positions in other companies held by directors' of a company indicates degree of linkage with external environment and resources. The market for outside directorships provides an important source of incentives for outside directors to develop reputation as monitoring specialists (Fama [93]; Fama and Jensen [94]). This reputation hypothesis tells that by sitting on many boards, an executive learns about different management styles or strategies used in other firms (Perry and Peyer [95]). Because of their competence and extensive experience they are more likely to serve on a larger number of board committees in comparison to those not holding multiple directorships. Thus, this hypothesis, predicts a positive relation between the number of board seats and the number of board committees (Jiraporn et al. [96]).

Ferris et al. [97] has termed directors holding position of directors in multiple companies in terms of busyness hypothesis. Multiple directorships permit a firm to use its directors to form or solidify advantageous contracting relations with other firms, such as important suppliers or customers (Ferris et al. [97]). However, individuals holding more outside board seats have less time to spend serv- 
ing on board committees. Sometimes executives may seek outside directorships because it improves their visibility and enhances their status, even at the cost of shareholders.

In this study, external busyness of directors has been measured in terms of average number of directorship and committee positions held in other companies by the directors of the company. In this regard some studies (e.g. Fich and Shivdasani [98]) view that a large number of appointments make directors over committed which leads to compromise over monitoring function affecting firm value adversely.

Studies have also found that directors with multiple appointments have positive impact on firm performance (Harris and Shimizu [99]; Ferris et al. [97]). This is based on the presumption that they have networks and corporations would benefit by accessing these resources (Booth and Deli [100]). In studies done in Indian context, it has been pointed out that occurrence of multiple directorship is also because of supply constraint in directors market, owing to lack of industrial leadership and adequacy of experience (Jackling and Johl [21]). Family control of business groups leads to directorship position held under kinship and social ties (Khanna and Rivkin [101]). Hence, outside directorship may not have positive association with firm value and this leads to our last hypothesis.

H9: Negative linkage between directors' external busyness and firm performance

\subsection{Control Variables}

Control variables used in the study are size of firm, age of firm, financial leverage employed by firm and sales growth of firm. Consideration of size of the company in terms of total assets as first control variable is in line with earlier studies in Indian context (Sarkar and Sarkar [28]; Kumar [31]; Black and Khanna [102]; Dharmapala and Khanna [32]; Balasubramian et al. [33]; Kota and Tomar [34]; Kumar and Singh [35]). In above mentioned studies, it is hypothesized that size has a positive influence on performance of the firm due to various reasons like diversification, economies of scale, access to cheaper sources of funds etc. In this study we have used natural logarithm of total assets as Firm size. Age of firm is another control variable considered in various studies in Indian Context (Sarkar and Sarkar [28]; Kumar [29]; Kota and Tomar [32]; Kumar and Singh [33]) and is calculated as difference between the year of study and the year of incorporation. It is hypothesized that older firms are more efficient than younger firms because of effect of the learning curve and survival bias. In this study, natural logarithm of the number of years since the incorporation is considered as Firm age.

Financial leverage of the firm has also been used as control variables in several studies (Sarkar and Sarkar [28]; Kumar [29]; Ehikioya [18]; Kota and Tomar [32]; Kumar and Singh [33]). It is calculated by dividing total liabilities with total stockholders' equity. A high debt/equity ratio generally means that a company is 
aggressive in financing its growth with debt. It is hypothesized that, if a firm uses debt to finance increased operations, the firm could potentially generate more earnings than it would have without this outside financing. Sales growth is used as control variable in the study and is calculated as total sales of the current year minus total sales in the previous year divided by total sales in the current year (Hermalin and Weisbach [103]).

\section{Research Design}

\subsection{Data and Sample}

The sampling frame includes Indian companies listed at National Stock exchange (NSE) for period of five financial years $31^{\text {st }}$ March 2013 to $31^{\text {st }}$ March 2018. Data of the listed firms has been taken from the prowess database of Centre for Monitoring of Indian Economy (CMIE). The data starting set is CNX 500 companies which accounts for about $95.77 \%$ of the free float market capitalization of the stocks listed on NSE (National stock exchange) as on March 31, 2018. Banks and financial companies (78 out of 500) were excluded from our sample due to their different accounting structure which makes it difficult to calculate the financial ratios used in study and following previous authors' example in this type of analysis (Yatim et al. [104]; Yammesri and Herath [76]; Jackling and Johl [21]; Black et al. [105]; Mustapha and Ahmad [106]; Vito and Bozec [107]; Kumar and Singh [41]). Further, we deleted companies not having full data for all variables under study for those 5 years. Hence, we were left with 391 companies with 5 year data resulting in 1955 data points. For some of the missing data like number of board meetings, CEO duality for some companies for some of the years we extracted data directly from the annual reports of respective companies.

\subsection{Variables and Measurement}

\subsubsection{Dependent Variables}

Researchers have used different parameters to measure firm performance. Tobin's $\mathrm{Q}$, a marked based performance measure is commonly used as a dependent variable (Agrawal and Knoeber [108]; Loderer and Peyer [109]; Perfect and Wiles [110]; Reddy et al. [111]; Kumar and Singh [41]). Tobin's Q is calculated as the market value of common stock and preferred stock plus book value of debt divided by the book value of assets.

Return on asset (ROA), an accounting based performance measure has also been used by many researchers (Demsetz and Villalonga [112]; Finch and Shivadasani [98], Thomsen et al. [113]). ROA is defined as ratio of after tax net operating income and the total operating assets (Copeland et al. [114]). Net operating income is computed as the operating earnings before income and taxes, before extra-ordinary items and prior adjustment. Prowess database of CMIE has an item called PBDITA (profit before depreciation interest and tax prior to extra-ordinary items). It has been used as a proxy for net operating income. 
Return on Equity (ROE), an accounting based performance measure has also been used by many researchers (Arora and Sharma [115]; Ayuso et al. [116], Vito and Bozec [107]; Sheikh et al. [66]; Crespi [117]; Drokos and Bekiris 2010; Jackling and Johl [21]; Guest [118]; Lam and Lee [83]; Beiner et al. [119]). ROE is defined as ratio operating profit before depreciation and amortization divided by total equity.

Demsetz and Villalonga [112] argue that although the numerator of Tobin's Q partly reflects the value that investors assign to a company's intangible assets, the denominator does not include investment the company has in intangible assets, such as, advertisement and research and development. These items are simply treated as expenses. To overcome this problem, some studies have used depreciated value of tangible assets. The accounting based profit measure is criticized as being backward looking and it only partially estimates future events in the form of depreciation and amortization. On the other hand, Tobin's $Q$ is greatly influenced by a wide range of unstable factors, such as, investors' psychology, and market forecasts (Reddy et al. [120]). For this reason we have used both types of performance measures in the study (Table 1).

\subsubsection{Independent Variables}

Corporate governance variables are considered as independent variables. Variables used in the study and their measures are indicated in Table 2.

\subsection{Data Analysis}

In this study data analysis is conducted with AMOS 21, a software package that estimates structural models with latent variables based on variance-covariance matrix. The causal modelling procedure followed in SEM is suitable to test the hypothesized model as the method considers multiple path coefficients simultaneously to allow analysis of direct, indirect and spurious relationship among variables and the technique estimates individual weightings of each observed variable in the context of theoretical model rather than in isolation. The model accommodates latent variables, measurement errors and inter-construct residual error, as well as reciprocal causation, simultaneity and interdependence (Capron et al. [121]). However, SEM requires a-priori formal specification of model and

Table 1. Dependent variables used in the study.

\begin{tabular}{|c|c|c|c|}
\hline S.No. & Variable name & Description & Measurement \\
\hline \multicolumn{4}{|c|}{ Dependent variables } \\
\hline 1 & Tobin's Q & $\begin{array}{l}\text { market value of equity }+ \text { book value of } \\
\text { short-term and long term debt divided by } \\
\text { total assets (FA + INV + CA) }\end{array}$ & ratio \\
\hline 2 & ROA & $\begin{array}{l}\text { operating profit before depreciation and } \\
\text { amortization divided by total assets }\end{array}$ & $\begin{array}{l}\text { ratio; considered as ratio of } \\
\text { PBDITA to total assets }\end{array}$ \\
\hline 3 & ROE & $\begin{array}{l}\text { operating profit before depreciation and } \\
\text { amortization divided by total equity }\end{array}$ & $\begin{array}{l}\text { ratio; considered as ratio of } \\
\text { PBDITA to total equity }\end{array}$ \\
\hline
\end{tabular}


Table 2. Independent variables used in the study.

\begin{tabular}{|c|c|c|c|}
\hline S.No. & $\begin{array}{l}\text { Variable } \\
\text { name }\end{array}$ & Description & Measurement \\
\hline \multicolumn{4}{|c|}{ Independent variables } \\
\hline \multicolumn{4}{|c|}{ Variables pertaining to ownership } \\
\hline 4 & PrOwn & $\begin{array}{l}\text { percentage of total equity ownership of promoter group } \\
\text { in the company }\end{array}$ & percentage \\
\hline 5 & InstOwn & $\begin{array}{l}\text { percentage of total equity ownership of institutional } \\
\text { investors in the company }\end{array}$ & percentage \\
\hline 6 & FFIOwn & $\begin{array}{l}\text { percentage of total equity ownership of foreign } \\
\text { institutional investors (FIIs) in the company }\end{array}$ & percentage \\
\hline \multicolumn{4}{|c|}{ Variables pertaining to board of directors } \\
\hline 7 & Bsize & number of directors on the board of a firm & number \\
\hline 8 & Bind & $\begin{array}{l}\text { percentage of outside directors of total number of } \\
\text { directors }\end{array}$ & percentage \\
\hline 9 & Bmeet & number of board meetings in a year & number \\
\hline 10 & Duality & $\begin{array}{l}\text { a binary variable if chairman of the board is also CEO of } \\
\text { the company its value is } 0 \\
\text { otherwise } 1\end{array}$ & binary number \\
\hline 11 & $\begin{array}{c}\text { Busyout } \\
\text { (OBUSYD) }\end{array}$ & $\begin{array}{l}\text { average number of directorship/chairmanship position } \\
\text { held by the directors of a company in other companies }\end{array}$ & number \\
\hline 12 & $\begin{array}{l}\text { Busyout } \\
\text { (OBUSYC) }\end{array}$ & $\begin{array}{l}\text { average number of committee position held by the } \\
\text { directors of a company in other companies }\end{array}$ & number \\
\hline 13 & $\begin{array}{l}\text { Busyin } \\
\text { (IBUSY) }\end{array}$ & $\begin{array}{l}\text { average number of board meeting attended by the } \\
\text { directors of a company }\end{array}$ & number \\
\hline \multicolumn{4}{|c|}{ Control variables } \\
\hline 14 & Fsize & natural logarithm of total assets & number \\
\hline 15 & Fage & $\begin{array}{l}\text { natural logarithm of the number of years since the } \\
\text { establishment }\end{array}$ & number \\
\hline 16 & Lev & ratio of long term debt to the total assets & ratio \\
\hline 17 & Sgrowth & $\begin{array}{l}\text { total sales of the current year minus total sales in the } \\
\text { previous year divided by total sales in the current year }\end{array}$ & percentage \\
\hline
\end{tabular}

statistical tests and assessment of fit can become ambiguous. The measurement goodness of fit of the model is assessed using several criteria as detailed in Table 3 .

Based on literature review a-priori formal specification of model is indicated in Figure 1.

For understanding the relationship between corporate governance and firm performance following four models have been analyzed in this study:

Model 1: Complete model with latent construct for ownership structure and board structure

Model 2: Complete model with only exogenous variables

Model 3: Ownership and firm performance model

Model 4: Board of directors and firm performance model 
Table 3. Criteria for acceptance of goodness of fit.

\begin{tabular}{|c|c|c|}
\hline S.no. & Type of fit & Acceptance criteria \\
\hline \multirow[t]{3}{*}{1} & Absolute model fit & Chi-square value and probability value $p>0.05$ \\
\hline & & Root mean square error of approximation $($ RMSEA) $<0.08$ \\
\hline & & Goodness of fit index $(\mathrm{GFI})>0.9$ \\
\hline \multirow[t]{4}{*}{2} & Incremental model fit & Adjusted goodness of fit index $($ AGFI $)>0.9$ \\
\hline & & Comparative fit index $(\mathrm{CFI})>0.9$ \\
\hline & & Normed fit index $(\mathrm{NFI})>0.9$ \\
\hline & & Tucker Lewis fit index $(\mathrm{TLI})>0.9$ \\
\hline 3 & Parsimonious model fit & Minimum discrepancy $=($ Chi square $/ \mathrm{df})<5$ \\
\hline
\end{tabular}

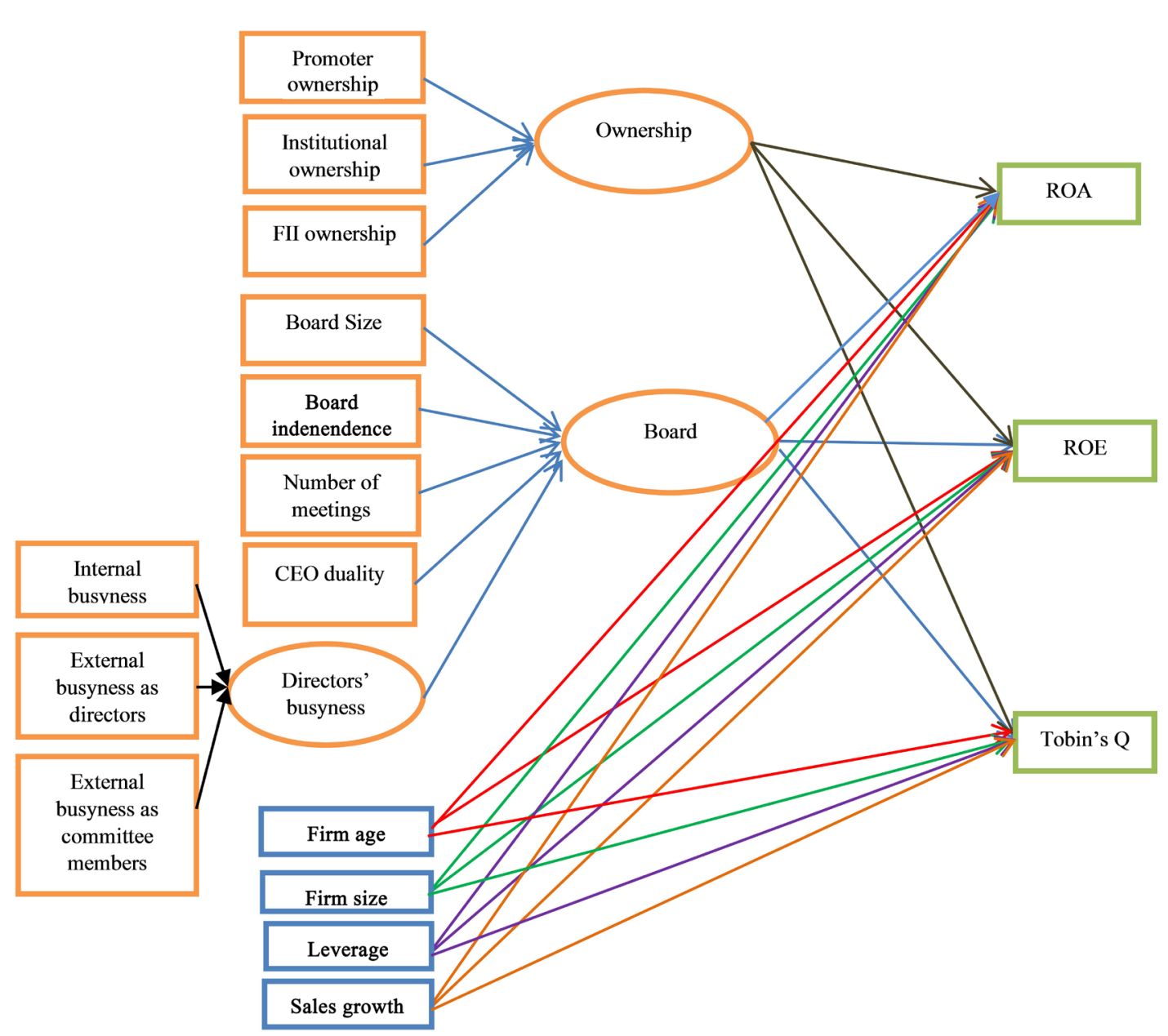

Figure 1. Formal specification of model.

\section{Result}

The descriptive analysis and correlation of the data are presented in Table 4. Market based performance variable Tobin's Q has mean (std. dev.) 1.90 (2.06) showing high variability. Accounting based performance variable ROA has mean (std. dev.) 0.15 (0.10), another accounting based performance variable ROE has mean (std. dev.) 0.34 (0.24). It reflects the fact that accounting based performance 


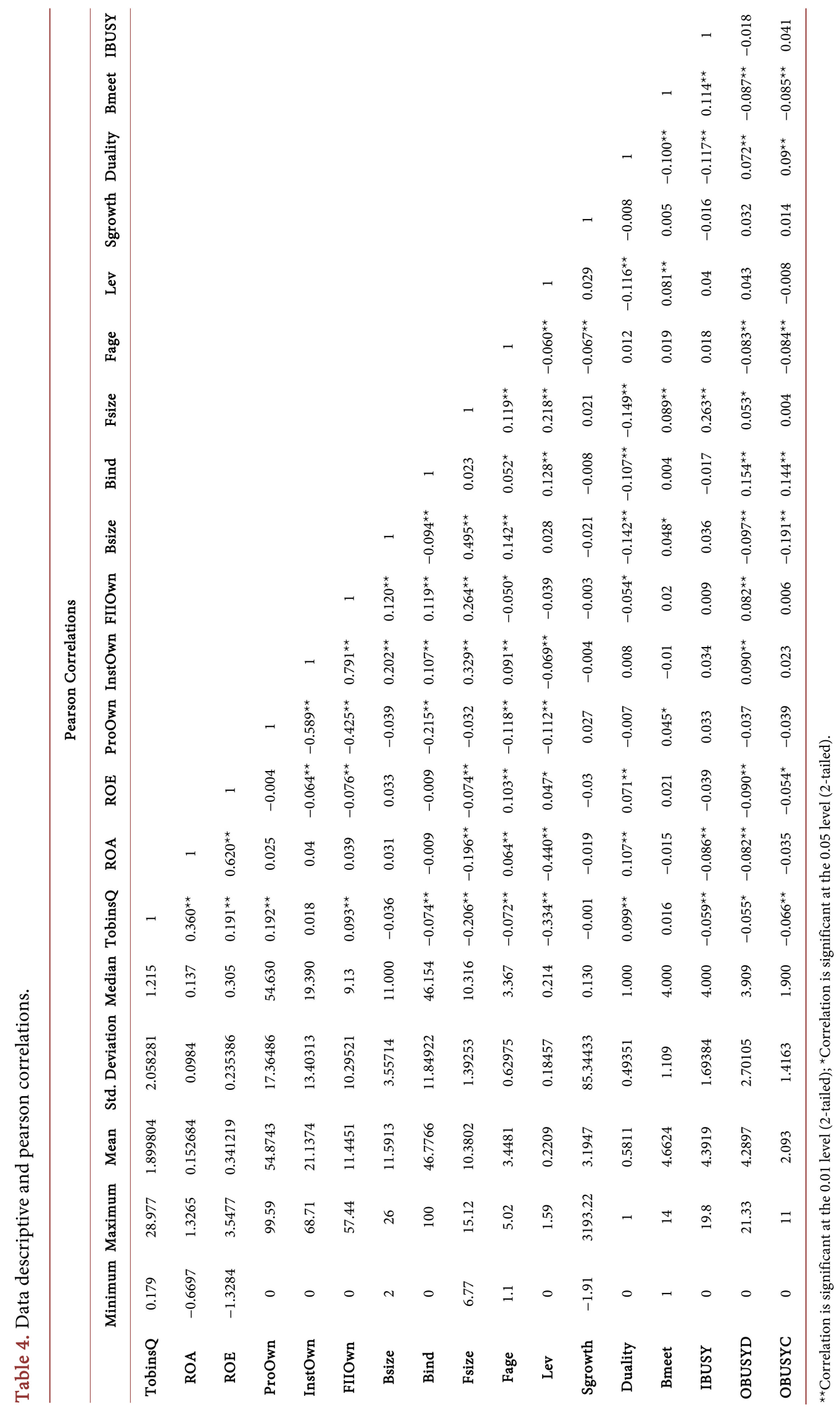


measure (ROA) has lesser variability in comparison to market based performance measure (Tobin's Q). Promoter ownership varies from 0 to 99.59 percent with mean (std. dev.) 54.87 (17.63). Median value of promoter ownership is 54.63 percent indicating that in Indian companies promoters are maintaining the controlling stake. Institutional ownership varies from 0 to 68.71 percent with mean (std. dev.) 21.14 (13.4). FII ownership varies from 0 to 57.44 percent with mean (std. dev.) 11.45 (10.3).

Board size measured by number of directors varies from 2 to 26 with mean (std. dev.) 11.59 (3.56). Board independence measured by percentage of independent directors to the total number of directors varies from 0 to 100 with mean (std. dev.) 46.78 (11.85). Number of board meetings (Bmeet) varies from 1 to 4 mean (std. dev.) 4.7 (1.1). Median value of Bmeet is 4 indicating that on an average board of Indian companies meet once in a quarter. Duality mean value is 0.58 indicating more number of Indian companies has roles of CEO and chairman of board of directors separated rather than combined in one person. Internal busyness of directors (IBUSY) has mean (std. dev.) 4.39 (1.69) indicating on an average a director attend more than 4 board meetings. External busyness of directors as director in other companies (OBUSYD) has mean (std. dev.) 4.29 (2.70) indicating on an average a director is on the board of more than 4 other companies. External busyness of directors as committee members in other companies (OBUSYC) has mean (std. dev.) 2.1 (1.4) indicating on an average a director is serving in more than 2 committees of other companies.

The size of firm in terms of total asset value varies between Rs.872 million to Rs.3,677,440 million with mean (std. dev.) Rs. million 101,188 (267,110). The median value is Rs.30199 million. Leverage mean (std. dev.) value is $0.22(0.18)$ showing that Indian companies depend more on equity rather than debt. For sales growth value of mean (std. dev.) is 3.2 (81.3) indicating very high variability.

\section{Testing of Hypotheses}

\section{Model 1: Complete model with latent construct for ownership structure} and board structure

Path diagram for the model is shown in Figure 2. Three endogenous latent variables are used in the model namely Ownership, Board and Directors' busyness. In this study we assume that three variables namely promoter ownership, institutional ownership and FII ownership strongly affect the latent construct. Latent construct board is assumed to be affected by measured variables board size, board independence, CEO duality, board meetings and latent construct busyness of directors. Latent construct busyness of directors is assumed to be affected by measured variables internal busyness of directors, external busyness of directors as director in other companies and external busyness of directors as committee member in other companies. Exogenous variables used are of three types; first representing firm performance namely Tobin's Q, ROA and ROE, second representing corporate governance variables and third representing control 


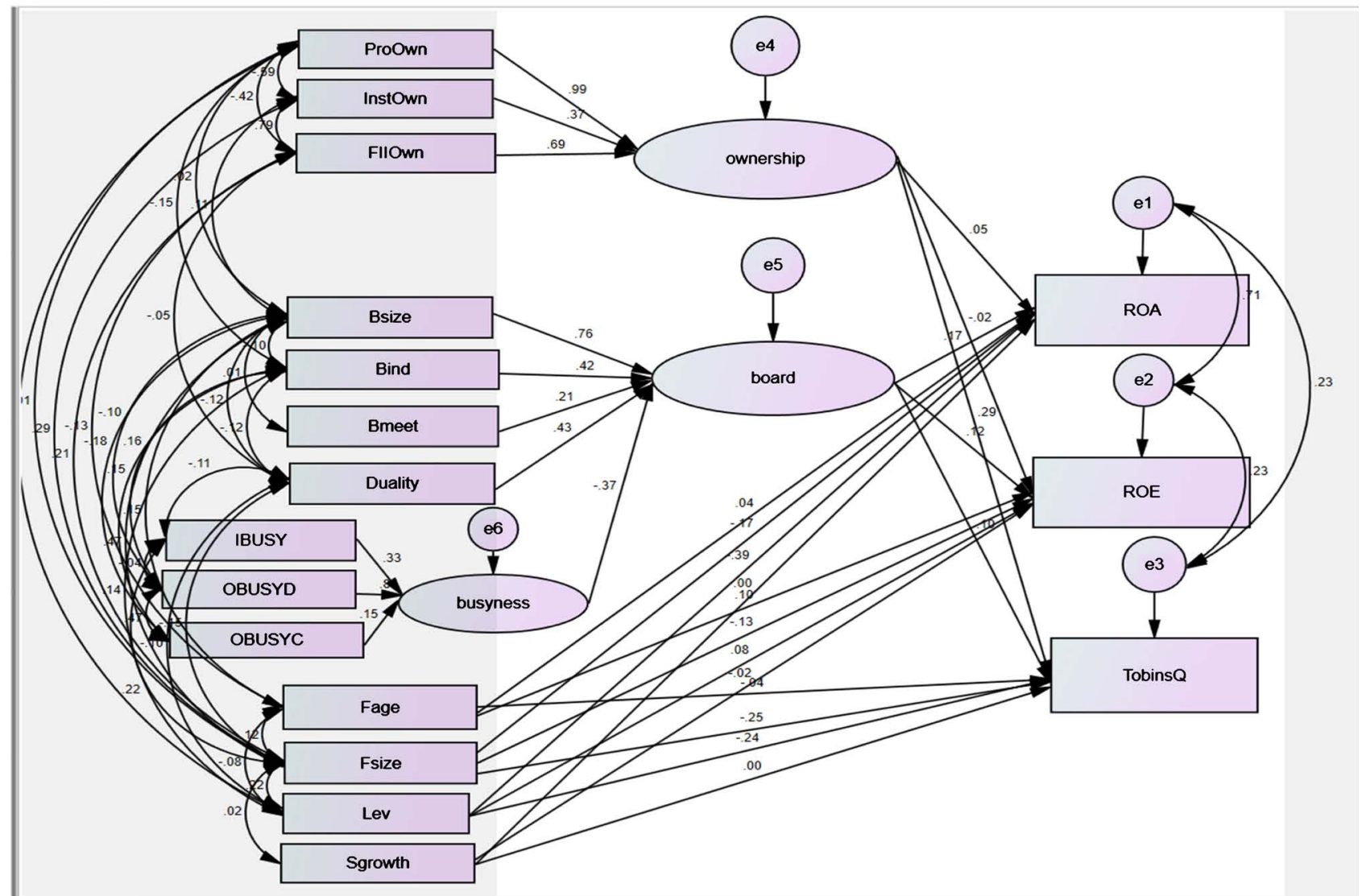

Figure 2. Path diagram with standardized estimates for complete model with latent construct for ownership structure and board structure.

variables viz. firm size, firm age, leverage and sales growth.

From the result presented in Table 5 it is indicated that the model fit is acceptable under all the three acceptance criteria viz. absolute model fit, incremental model fit and parsimonious model fit.

Latent construct board of directors (board) is positively and significantly impacting all three performance measures namely Tobin's Q, ROA and ROE. The latent construct ownership is positively and significantly impacting performance measures Tobin' $\mathrm{Q}$ and ROA (at 5\%).

Among control variables firm size (Fsize) is impacting all three performance measures negatively and significantly. Firm age (Fage) is impacting performance variable ROE positively and significantly. Leverage is impacting performance variables Tobin's $Q$ and ROA negatively and significantly and performance variable ROE positively and significantly. Sales growth is not found to impact any of the performance variables significantly.

Latent construct ownership is positively and significantly impacted by all the three ownership variables namely promoter ownership (ProOwn), institutional ownership (InstOwn) and foreign institutional ownership (FIIOwn). Among the three ownership variables considered, promoter ownership is having highest impact on the latent construct ownership. FII ownership is having more impact 
Table 5. Parameters estimates and significance level for complete model with latent construct.

\begin{tabular}{|c|c|c|c|c|c|c|}
\hline \multicolumn{3}{|c|}{ Parameter estimates } & \multirow{2}{*}{$\begin{array}{c}\text { Estimate } \\
1\end{array}$} & \multirow[t]{2}{*}{ S.E. } & \multirow{2}{*}{$\begin{array}{c}\begin{array}{c}\text { Standardized } \\
\text { regression weights }\end{array} \\
0.335\end{array}$} & \multirow[t]{2}{*}{$\mathrm{p}$ valu } \\
\hline busyness & $<---$ & IBUSY & & & & \\
\hline busyness & $<---$ & OBUSYD & 1.598 & 1.584 & 0.853 & 0.313 \\
\hline busyness & $<---$ & OBUSYC & 0.535 & 1.314 & 0.15 & 0.684 \\
\hline ownership & $<---$ & ProOwn & 1 & & 0.992 & \\
\hline ownership & $<---$ & InstOwn & 0.494 & 0.15 & 0.374 & $* * *$ \\
\hline ownership & $<---$ & FIIOwn & 1.17 & 0.216 & 0.695 & $* * *$ \\
\hline board & $<---$ & Bsize & 1 & & 0.755 & \\
\hline board & $<---$ & Bind & 0.167 & 0.052 & 0.422 & 0.001 \\
\hline board & $<---$ & Bmeet & 0.893 & 0.495 & 0.211 & 0.071 \\
\hline board & $<---$ & Duality & 4.109 & 1.245 & 0.43 & $* * *$ \\
\hline board & $<---$ & busyness & -0.346 & 0.335 & -0.372 & 0.301 \\
\hline ROA & $<--$ & Fage & 0.006 & 0.003 & 0.04 & 0.05 \\
\hline ROE & $<---$ & Fage & 0.037 & 0.009 & 0.099 & $* * *$ \\
\hline TobinsQ & $<---$ & Fage & -0.124 & 0.068 & -0.038 & 0.067 \\
\hline ROA & $<---$ & Fsize & -0.013 & 0.002 & -0.173 & $* * *$ \\
\hline ROE & $<---$ & Fsize & -0.022 & 0.005 & -0.127 & $* * *$ \\
\hline TobinsQ & $<---$ & Fsize & -0.383 & 0.037 & -0.254 & $* * *$ \\
\hline ROA & $<---$ & Lev & -0.21 & 0.011 & -0.395 & $* * *$ \\
\hline $\mathrm{ROE}$ & $<---$ & Lev & 0.096 & 0.03 & 0.076 & 0.001 \\
\hline TobinsQ & $<---$ & Lev & -2.62 & 0.24 & -0.235 & $* * *$ \\
\hline ROA & $<---$ & Sgrowth & 0 & 0 & 0.002 & 0.911 \\
\hline $\mathrm{ROE}$ & $<---$ & Sgrowth & 0 & 0 & -0.019 & 0.395 \\
\hline TobinsQ & $<--$ & Sgrowth & 0 & 0 & 0.005 & 0.809 \\
\hline ROA & $<---$ & ownership & 0 & 0 & 0.052 & 0.018 \\
\hline $\mathrm{ROE}$ & $<---$ & ownership & 0 & 0 & -0.023 & 0.335 \\
\hline TobinsQ & $<---$ & ownership & 0.034 & 0.003 & 0.29 & $* * *$ \\
\hline ROA & $<--$ & board & 0.003 & 0.001 & 0.166 & $* * *$ \\
\hline $\mathrm{ROE}$ & $<--$ & board & 0.006 & 0.001 & 0.12 & $* * *$ \\
\hline TobinsQ & $<---$ & board & 0.045 & 0.011 & 0.104 & $* * *$ \\
\hline
\end{tabular}

Absolute model fit measures: $\mathrm{N}=1955$, Chi square $(74)=359.939, \mathrm{p}<0.001$, RMSEA $=0.044$; Incremental model fit measures: $\mathrm{TLI}=0.933, \mathrm{CFI}=0.964, \mathrm{NFI}=0.955$; Parsimonious model fit measures: $\mathrm{CMIN} / \mathrm{DF}=$ 4.864 .

compared to institutional ownership.

Latent construct board is positively and significantly impacted by variables board size (Bsize), board independence (Bind) and CEO duality (Duality). 


\section{Model 2: Complete model with only exogenous variables}

Path diagram for the model is shown in Figure 3. In this model all exogenous variables considered in the study are used to understand the impact of specific governance variable on performance. Exogenous variables used are of three types; first representing firm performance namely Tobin's Q, ROA and ROE, second representing corporate governance variables and third representing control variables viz. firm size, firm age, leverage and sales growth.

From the result presented in Table 6 it is indicated that the model fit is acceptable under all the three acceptance criteria viz. absolute model fit, incremental model fit and parsimonious model fit.

Promoter ownership (ProOwn), FII ownership (FIIOwn) and institutional ownership (InstOwn) are positively and significantly impacting market based performance measure Tobin's $Q$ and not impacting accounting based performance measure (ROA and ROE) significantly.

Size of the board is impacting positively and significantly the performance

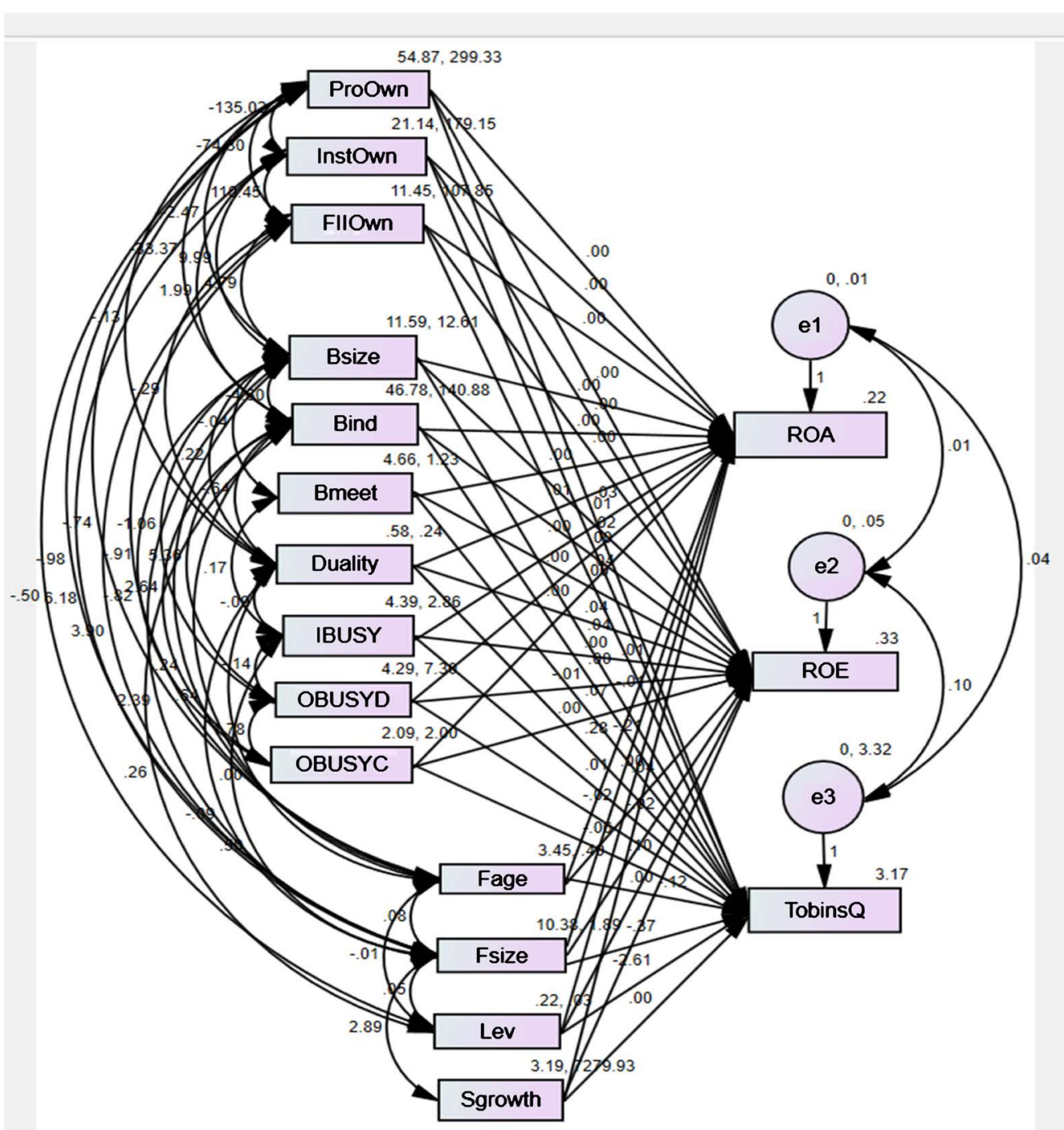

Figure 3. Path diagram with standardized estimates for complete model with only exogenous variable. 
Table 6. Parameters estimates and significance level for model with only exogenous variable.

\begin{tabular}{|c|c|c|c|c|c|c|}
\hline \multicolumn{3}{|c|}{ Parameter estimates } & \multirow{2}{*}{$\begin{array}{c}\text { Estimate } \\
0.006\end{array}$} & \multirow{2}{*}{$\begin{array}{l}\text { S.E. } \\
0.003\end{array}$} & \multirow{2}{*}{$\begin{array}{c}\begin{array}{c}\text { Standardized } \\
\text { regression weights }\end{array} \\
0.041\end{array}$} & \multirow{2}{*}{$\begin{array}{r}\text { p value } \\
0.047\end{array}$} \\
\hline $\mathrm{ROA}$ & $<---$ & Fage & & & & \\
\hline ROE & $<---$ & Fage & 0.038 & 0.009 & 0.102 & $* * *$ \\
\hline TobinsQ & $<---$ & Fage & -0.125 & 0.068 & -0.038 & 0.067 \\
\hline ROA & $<---$ & Fsize & -0.013 & 0.002 & -0.180 & $* * *$ \\
\hline ROE & $<---$ & Fsize & -0.019 & 0.005 & -0.112 & $* * *$ \\
\hline TobinsQ & $<---$ & Fsize & -0.369 & 0.040 & -0.247 & $* * *$ \\
\hline ROA & $<---$ & Lev & -0.210 & 0.011 & -0.396 & $* * *$ \\
\hline ROE & $<---$ & Lev & 0.104 & 0.031 & 0.082 & $* * *$ \\
\hline TobinsQ & $<---$ & Lev & -2.605 & 0.241 & -0.234 & $* * *$ \\
\hline ROA & $<---$ & Sgrowth & 0.000 & 0.000 & 0.003 & 0.879 \\
\hline ROE & $<---$ & Sgrowth & 0.000 & 0.000 & -0.019 & 0.397 \\
\hline TobinsQ & $<---$ & Sgrowth & 0.000 & 0.000 & 0.005 & 0.817 \\
\hline ROA & $<--$ & ProOwn & 0.000 & 0.000 & 0.029 & 0.273 \\
\hline ROE & $<---$ & ProOwn & 0.000 & 0.000 & -0.012 & 0.683 \\
\hline TobinsQ & $<---$ & FIIOwn & 0.038 & 0.007 & 0.193 & $* * *$ \\
\hline ROA & $<---$ & Bsize & 0.004 & 0.001 & 0.129 & $* * *$ \\
\hline TobinsQ & $<---$ & Bsize & 0.039 & 0.014 & 0.067 & 0.006 \\
\hline ROA & $<---$ & InstOwn & 0.000 & 0.000 & 0.007 & 0.865 \\
\hline $\mathrm{ROE}$ & $<---$ & InstOwn & -0.001 & 0.001 & -0.039 & 0.376 \\
\hline TobinsQ & $<---$ & InstOwn & 0.015 & 0.006 & 0.098 & 0.013 \\
\hline TobinsQ & $<---$ & ProOwn & 0.035 & 0.003 & 0.294 & $* * *$ \\
\hline ROE & $<---$ & FIIOwn & 0.000 & 0.001 & -0.013 & 0.728 \\
\hline $\mathrm{ROA}$ & $<---$ & FIIOwn & 0.001 & 0.000 & 0.066 & 0.050 \\
\hline ROA & $<---$ & Bind & 0.001 & 0.000 & 0.068 & 0.001 \\
\hline ROE & $<---$ & Bind & 0.000 & 0.000 & 0.008 & 0.727 \\
\hline TobinsQ & $<---$ & Bind & 0.003 & 0.004 & 0.018 & 0.409 \\
\hline ROA & $<---$ & Bmeet & 0.002 & 0.002 & 0.028 & 0.158 \\
\hline $\mathrm{ROE}$ & $<---$ & Bmeet & 0.005 & 0.005 & 0.022 & 0.324 \\
\hline TobinsQ & $<---$ & Bmeet & 0.072 & 0.037 & 0.039 & 0.055 \\
\hline ROA & $<---$ & Duality & 0.013 & 0.004 & 0.067 & 0.001 \\
\hline ROE & $<---$ & Duality & 0.038 & 0.011 & 0.080 & $* * *$ \\
\hline TobinsQ & $<---$ & Duality & 0.283 & 0.086 & 0.068 & 0.001 \\
\hline ROA & $<---$ & IBUSY & -0.001 & 0.001 & -0.025 & 0.225 \\
\hline ROE & $<---$ & IBUSY & -0.001 & 0.003 & -0.010 & 0.656 \\
\hline TobinsQ & $<---$ & IBUSY & 0.005 & 0.026 & 0.004 & 0.835 \\
\hline
\end{tabular}




\begin{tabular}{ccccccc} 
Continued & \multicolumn{7}{c}{} \\
\hline ROA & $<---$ & OBUSYD & -0.002 & 0.001 & -0.061 & 0.007 \\
ROE & $<---$ & OBUSYD & -0.006 & 0.002 & -0.072 & 0.004 \\
TobinsQ & $<---$ & OBUSYD & -0.021 & 0.017 & -0.028 & 0.228 \\
ROA & $<---$ & OBUSYC & 0.000 & 0.002 & 0.007 & 0.764 \\
ROE & $<---$ & OBUSYC & 0.000 & 0.004 & 0.000 & 0.998 \\
ROE & $<--$ & Bsize & 0.006 & 0.002 & 0.085 & 0.001 \\
TobinsQ & $<---$ & OBUSYC & -0.061 & 0.033 & -0.042 & 0.070 \\
\hline
\end{tabular}

Absolute model fit measures: $\mathrm{N}=1955$, Chi square $(52)=258.376, \mathrm{p}<0.001$, RMSEA $=0.045$; Incremental model fit measures: $\mathrm{TLI}=0.931, \mathrm{CFI}=0.974, \mathrm{NFI}=0.968$; Parsimonious model fit measures: $\mathrm{CMIN} / \mathrm{DF}=$ 4.969 .

variables ROA, Tobin's Q and ROE.

Board independence (Bind) is impacting positively and significantly (at 5\%) the performance variable ROA and not impacting Tobin's and ROE significantly.

Board meeting (Bmeet) is not impacting any of the performance variables.

CEO duality (Duality) is impacting the performance variables ROA, Tobin's Q and ROE positively and significantly.

Internal busyness of director (IBUSY) and external busyness of director as committee members in other companies (OBUSYC) are not significantly impacting any of the three performance variables namely Tobin's Q, ROA and ROE.

External busyness of director as directors in other companies (OBUSYD) is negatively and significantly impacting performance variables ROA and ROE and not impacting performance variable Tobin's Q significantly.

Among control variables firm size (Fsize) is impacting all three performance measures negatively and significantly. Firm age (Fage) is impacting performance variable ROE positively and significantly and also impacting ROA positively and significantly (at 5\%) and not impacting Tobin's Q significantly. Leverage is impacting performance variables Tobin's $Q$ and ROA negatively and significantly and performance variable ROE positively and significantly. Sales growth is not found to impact any of the performance variables significantly.

\section{Model 3: Ownership and firm performance model}

Path diagram for the model is shown in Figure 4. In this model one latent construct ownership is used, which is assumed to be affected by three measured variables namely promoter ownership, institutional ownership and FII ownership. Exogenous variables used are of two types; first representing firm performance namely Tobin's Q, ROA and ROE, second representing control variables viz. firm size, firm age, leverage and sales growth.

From the result presented in Table 7 it is indicated the model fit is acceptable under all three acceptance criteria viz. absolute model fit, incremental model fit and parsimonious model fit.

Latent construct ownership is positively and significantly impacted by all the 


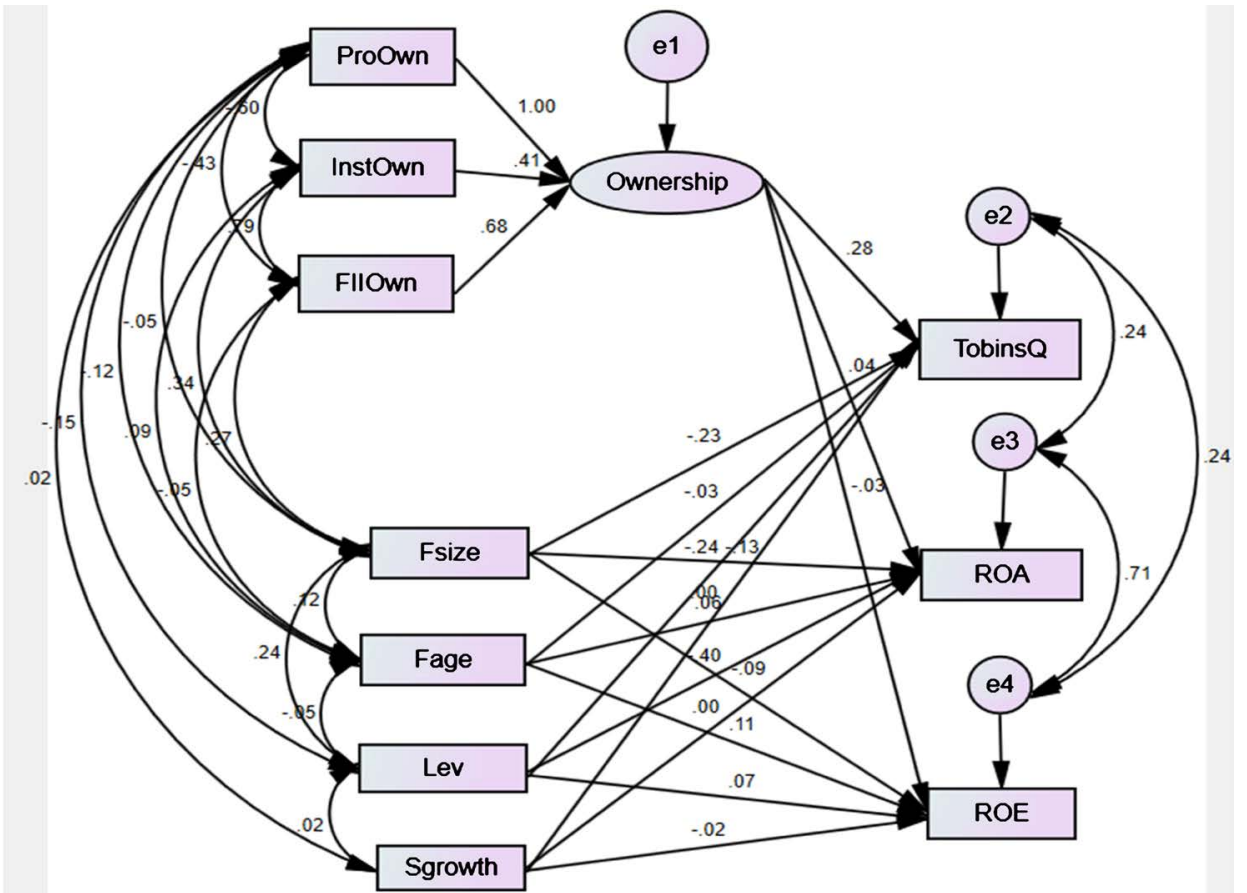

Figure 4. Path diagram with standardized estimates for ownership and firm performance model.

Table 7. Parameters estimates and significance level for ownership and firm performance model.

\begin{tabular}{ccccccc}
\hline \multicolumn{2}{c}{ Parameter estimates } & Estimate & S.E. & $\begin{array}{c}\text { Standardized } \\
\text { Regression weights }\end{array}$ & p value \\
\hline Ownership & $<---$ & ProOwn & 1 & & 0.996 & \\
Ownership & $<---$ & InstOwn & 0.531 & 0.153 & 0.406 & $* * *$ \\
Ownership & $<---$ & FIIOwn & 1.163 & 0.221 & 0.682 & $* * *$ \\
TobinsQ & $<---$ & Ownership & 0.033 & 0.003 & 0.283 & $* * *$ \\
ROA & $<---$ & Ownership & 0.000 & 0.000 & 0.044 & 0.045 \\
ROE & $<---$ & Ownership & 0.000 & 0.000 & -0.030 & 0.221 \\
TobinsQ & $<---$ & Fsize & -0.341 & 0.034 & -0.232 & $* * *$ \\
ROA & $<---$ & Fsize & -0.009 & 0.002 & -0.129 & $* * *$ \\
ROE & $<---$ & Fsize & -0.016 & 0.004 & -0.095 & $* * *$ \\
TobinsQ & $<---$ & Fage & -0.085 & 0.068 & -0.026 & 0.213 \\
ROA & $<---$ & Fage & 0.009 & 0.003 & 0.060 & 0.004 \\
ROE & $<---$ & Fage & 0.042 & 0.009 & 0.113 & $* * *$ \\
TobinsQ & $<---$ & Lev & -2.662 & 0.242 & -0.238 & $* * *$ \\
ROA & $<---$ & Lev & -0.214 & 0.011 & -0.400 & $* * *$ \\
ROE & $<---$ & Lev & 0.090 & 0.030 & 0.070 & 0.003 \\
TobinsQ & $<---$ & Sgrowth & 0.000 & 0.000 & 0.002 & 0.913 \\
ROA & $<---$ & Sgrowth & 0.000 & 0.000 & -0.002 & 0.915 \\
ROE & $<---$ & Sgrowth & 0.000 & 0.000 & -0.022 & 0.324 \\
\hline
\end{tabular}

Absolute model fit measures: $\mathrm{N}=1955$, Chi square $(10)=46.686, \mathrm{p}<0.001$, RMSEA $=0.043$; Incremental model fit measures: TLI $=0.972, \mathrm{CFI}=0.994, \mathrm{NFI}=0.992$; Parsimonious model fit measures: $\mathrm{CMIN} / \mathrm{DF}=4.669$. 
three ownership variables namely promoter ownership (ProOwn), institutional ownership (InstOwn) and foreign institutional ownership (FIIOwn). Among the three, promoter ownership is having highest impact on the latent construct ownership. FII ownership is having more impact compared to institutional ownership.

Ownership is impacting Tobin's Q positively and significantly and also ROA positively and significantly (at 5\%) and not impacting ROE significantly.

Among control variables firm size (Fsize) is impacting all three performance measures negatively and significantly. Firm age (Fage) is impacting performance variable ROE positively and significantly and also impacting ROA positively and significantly and not impacting Tobin's Q significantly. Leverage is impacting performance variables Tobin's $Q$ and ROA negatively and significantly and performance variable ROE positively and significantly. Sales growth is not found to impact any of the performance variables significantly.

\section{Model 4: Board of directors and firm performance model}

Path diagram for the model is shown in Figure 5. In this model two endogenous latent constructs are used namely board and directors' busyness. Latent

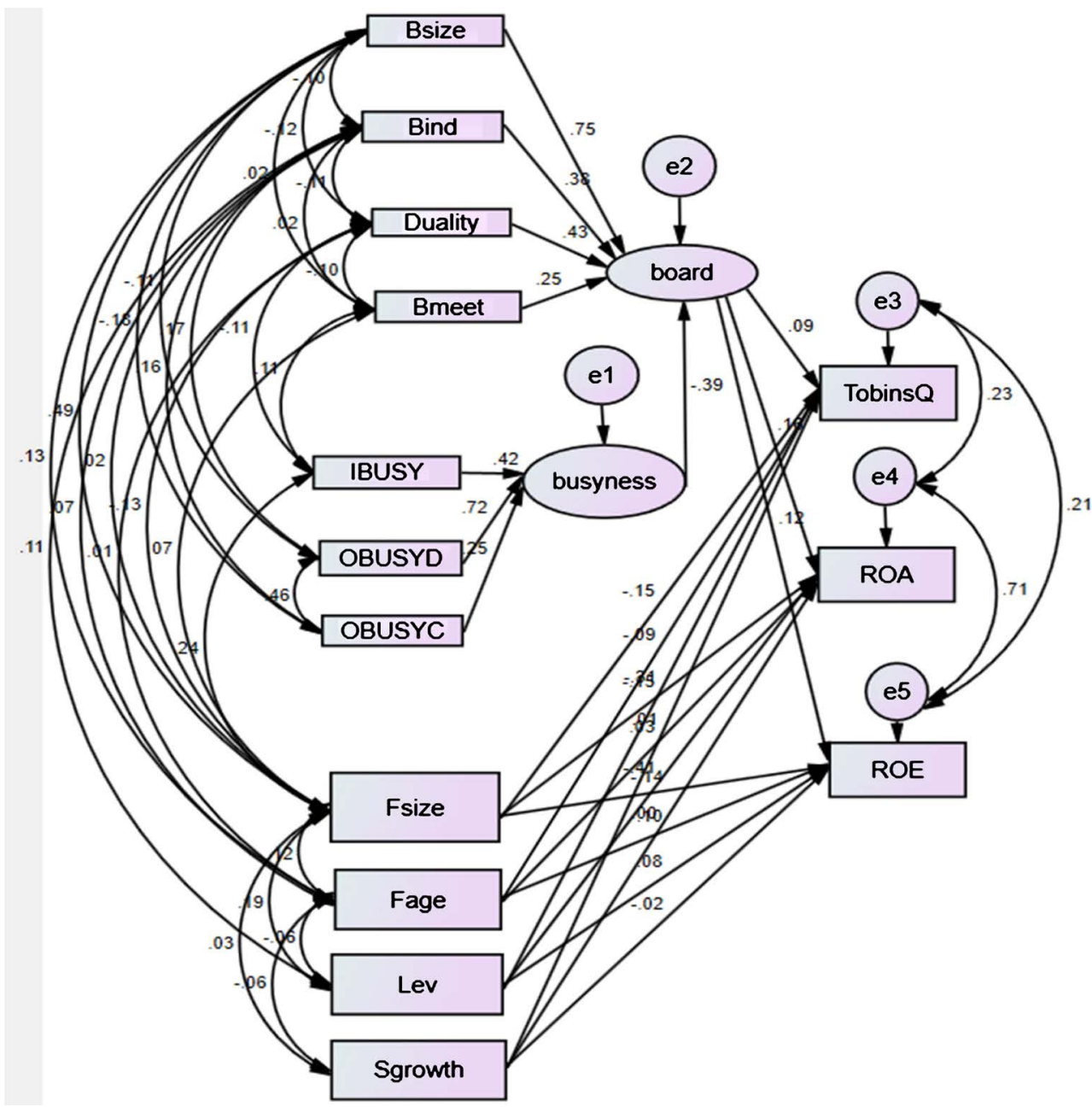

Figure 5. Path diagram with standardized estimates for board of directors and firm performance model. 
construct board is assumed to be affected by measured variables board size, board independence, CEO duality, board meetings and latent construct busyness of directors. Latent construct busyness of directors is assumed to be affected by measured variables internal busyness of directors, external busyness of directors as director in other companies and external busyness of directors as committee member in other companies. Exogenous variables used are of three types; first representing firm performance namely Tobin's Q, ROA and ROE, second representing corporate governance variables and third representing control variables viz. firm size, firm age, leverage and sales growth.

From the result presented in Table 8 it is indicated that the model fit is acceptable

Table 8. Parameters estimates and significance level for board of directors and firm performance model.

\begin{tabular}{|c|c|c|c|c|c|c|}
\hline \multicolumn{3}{|c|}{ Parameter estimates } & \multirow{2}{*}{$\begin{array}{c}\text { Estimate } \\
1\end{array}$} & \multirow[t]{2}{*}{ S.E. } & \multirow{2}{*}{$\begin{array}{c}\begin{array}{c}\text { Standardized } \\
\text { regression weights }\end{array} \\
0.422\end{array}$} & \multirow[t]{2}{*}{$\mathrm{p}$ value } \\
\hline busyness & $<---$ & IBUSY & & & & \\
\hline busyness & $<--$ & OBUSYD & 1.077 & 0.941 & 0.725 & 0.252 \\
\hline busyness & $<---$ & OBUSYC & 0.719 & 1.095 & 0.254 & 0.511 \\
\hline board & $<---$ & Bsize & 1 & & 0.747 & \\
\hline board & $<---$ & Bind & 0.151 & 0.054 & 0.378 & 0.005 \\
\hline board & $<---$ & Duality & 4.142 & 1.333 & 0.430 & 0.002 \\
\hline board & $<---$ & Bmeet & 1.086 & 0.545 & 0.253 & 0.046 \\
\hline board & $<---$ & busyness & -0.465 & 0.368 & -0.393 & 0.207 \\
\hline TobinsQ & $<---$ & board & 0.041 & 0.011 & 0.095 & $* * *$ \\
\hline ROA & $<---$ & board & 0.003 & 0.001 & 0.162 & $* * *$ \\
\hline $\mathrm{ROE}$ & $<---$ & board & 0.006 & 0.001 & 0.122 & $* * *$ \\
\hline TobinsQ & $<---$ & Fsize & -0.228 & 0.035 & -0.153 & $* * *$ \\
\hline ROA & $<---$ & Fsize & -0.011 & 0.002 & -0.155 & $* * *$ \\
\hline ROE & $<---$ & Fsize & -0.023 & 0.004 & -0.136 & $* * *$ \\
\hline TobinsQ & $<---$ & Fage & -0.284 & 0.070 & -0.087 & $* * *$ \\
\hline $\mathrm{ROA}$ & $<---$ & Fage & 0.005 & 0.003 & 0.032 & 0.117 \\
\hline $\mathrm{ROE}$ & $<---$ & Fage & 0.038 & 0.008 & 0.102 & $* * *$ \\
\hline TobinsQ & $<---$ & Lev & -3.434 & 0.240 & -0.309 & $* * *$ \\
\hline ROA & $<---$ & Lev & -0.217 & 0.011 & -0.409 & $* * *$ \\
\hline $\mathrm{ROE}$ & $<---$ & Lev & 0.104 & 0.029 & 0.081 & $* * *$ \\
\hline TobinsQ & $<---$ & Sgrowth & 0.000 & 0.001 & 0.008 & 0.708 \\
\hline $\mathrm{ROA}$ & $<---$ & Sgrowth & 0.000 & 0 & 0.002 & 0.905 \\
\hline ROE & $<---$ & Sgrowth & 0.000 & 0 & -0.019 & 0.384 \\
\hline
\end{tabular}

Absolute model fit measures: $\mathrm{N}=1955$, Chi square $(40)=165.704, \mathrm{p}<0.001$, RMSEA $=0.040$; Incremental model fit measures: $\mathrm{TLI}=0.931, \mathrm{CFI}=0.970, \mathrm{NFI}=0.961$; Parsimonious model fit measures: $\mathrm{CMIN} / \mathrm{DF}=$ 4.143 . 
under all the three acceptance criteria viz. absolute model fit, incremental model fit and parsimonious model fit.

Latent construct board of directors (board) is positively and significantly impacted by board size (Bsize), board independence (Bind), separated roles of CEO and chairman of the board (Duality) and number of board meetings (Bmeet).

The latent construct board is found to impact positively and significantly all three performance measures namely Tobin's $\mathrm{Q}, \mathrm{ROA}$ and ROE.

Among control variables firm size (Fsize) is impacting all three performance measures negatively and significantly. Firm age (Fage) is impacting performance variable ROE positively and significantly and impacting Tobin's $Q$ negatively and significantly and not impacting ROA significantly. Leverage is impacting performance variables Tobin's $\mathrm{Q}$ and ROA negatively and significantly and performance variable ROE positively and significantly. Sales growth is not found to impact any of the performance variables significantly.

\section{Discussion}

Ownership is found positively and significantly affecting performance variables Tobin's Q and ROA and not impacting ROE (model 1 and 3). This is in line with earlier studies in Indian context (Kumar [29]; Dwivedi and Jain [122]; Jackling and Johl [21]; Bhaumik et al. [123]; Kumar and Singh [41]), indicating influence of ownership structure on firm performance. It is also indicated that latent construct ownership is impacted most by exogenous variable promoter ownership followed by FII ownership and then institutional ownership.

When ownership constituents (exogenous ownership variables) are considered for their impact on performance variables (model 2); all the three ownership variables viz. promoter ownership, FII ownership and institutional ownership are impacting Tobin's $Q$ positively and significantly but not impacting ROA and ROE. Thus, Hypotheses H1, H2 and $\mathrm{H} 3$ are supported for marked based performance measure and not supported for accounting based performance measures.

Support for $\mathrm{H} 1$ is validating applicability of agency theory in Indian context. Higher promoter ownership is leading to higher promoter control and alignment of interest is leading to better firm performance. High promoter ownership in a company, help them to take important decisions and drive its performance (Kumar and Singh [41]). Our findings validate the findings of similar studies (viz. Selarka [124]; Kumar and Singh [41]) done in the same context.

Support for $\mathrm{H} 2$ may be attributed to higher monitoring potential of institution. This significant finding may be attributed to the effects of economic reforms initiated in last decade of last century. Prior to economic reforms Indian financial institutions failed to perform monitoring function (Khanna and Palepu [13] [14]). Prevailing government policy at that time directed financial institutions to maximize loans to the industrial sector under the belief that it could lead to industrial development. Further, institutions were also instructed not to dis- 
turb the management. Because of this kind of policy financial institutions had neither any threat of competition nor any incentive to monitor the behaviour of the management. The economic reforms and subsequent creation of regulatory body like Stock Exchange Board of India (SEBI) with the explicit mandate to improve the functioning of Indian financial markets led to increase in monitoring potential and incentive for domestic institutions.

Support for H3 is in line with Douma et al. [60] who found positive effect of foreign ownership on performance of Indian companies which is attributable to foreign ownership that have, on an average, large shareholding and a higher degree of commitment and long term involvement. Significant foreign ownership particularly beyond control level provides opportunity to deploy practices of developed economies for better performance. This is in line with Chhiber and Majumdar (1999), who found Indian companies at unambiguous control level display relatively better performance.

Board of directors is found positively and significantly affecting all three performance variables Tobin's Q, ROA and ROE (model 1 and 4). Further, it is indicated that exogenous variables impacting board of directors are board size, board independence and CEO duality.

When exogenous variables pertaining to board of directors are considered for their impact on performance variables (model 2) board size is impacting all three performance variables positively and significantly. So, H4 is not supported rather it is opposite. This is in line with Dwivedi and Jain [124] who found a positive relationship between board size and Tobin's Q, however, it contradicts the negative relationship observed by Ghosh [125] and Kumar and Singh [41]. The result is also in line with Jackling and Johl [21], who found a significant and positive association between board size and firm performance. This result is reflecting contextual aspect of Indian corporate environment, where requirement of bigger board size is giving credence to resource dependence theory.

Board independence is impacting ROA positively and significantly but not impacting Tobin's $\mathrm{Q}$ and ROE. So, H5 is supported for performance variable ROA and not supported for performance variables Tobin's $Q$ and ROE.

Board meeting is impacting Tobin's $Q$ positively and significantly and not impacting ROA and ROE. So, H6 is supported for market based performance measure and not supported for accounting based performance measures.

CEO duality is impacting all three performance measures Tobin's Q, ROA and ROE positively and significantly. As we have defined duality as binary variable taking value 0 when both the roles (CEO and chairman of board of directors) are combined into one person and having value 1 when both the roles are separated. So, result is indicating that separated role of CEO and Chairman of board of directors is impacting firm performance positively and significantly. Thus, $\mathrm{H} 7 \mathrm{is}$ supported for all three performance measures.

Internal busyness of directors (IBUSY) is not impacting any of the performance variables, so, $\mathrm{H} 8$ is not supported. 
External busyness of director as directors in other companies (OBUSYD) is impacting ROA and ROE negatively and significantly and not impacting Tobin's Q. So, H9 is supported for accounting based performance measure and is not supported for market based performance measure. Hence, it is indicated that when directors hold too may outside positions, they become overburdened and their involvement in monitoring function of the board decreases leading to decreased firm performance. This is in line with Sarkar and Sarkar [126] who found multiple directorships by inside directors negatively related to firm performance.

\section{Conclusions}

This study explores the relationship between corporate governance structure and firm performance measured by Tobin's Q, ROA and ROE. The results suggest that corporate governance variables affect market based performance measures (Tobin's Q) more in comparison to accounting based performance measures (ROA and ROE). Out of two governance mechanisms studied in the research for their impact on corporate performance, ownership structure appears to impact market based performance measure more whereas board structure appears to impact accounting based performance measure more. Impact on corporate performance is maximum for promoter ownership followed by FII ownership and then of institutional ownership among various ownership variables. Among board variables, board size is found to impact performance positively and CEO duality is found to impact performance negatively. Board independence is found to impact positively accounting based performance only, whereas the number of board meetings is found to impact positively market based performance measure only. Directors' internal busyness is not found to impact any of the performance measures. As far as directors' external busyness is concerned, it is impacting accounting based measures negatively when the busyness is measured in terms of position of directors in other companies. Firm size is found to impact performance negatively. In general, firm age is found to impact accounting based performance measure positively and not impacting market based performance measure. Leverage is impacting performance measures Tobin's $\mathrm{Q}$ and ROA negatively; however, it impacts ROE positively.

This study is a comprehensive addition to the body of existing studies on corporate governance specifically in Indian context. The dataset for corporate governance attributes and firm performance is quite comprehensive and contemporary. The empirical findings supported agency theory and resource dependency theory and validated that the corporate governance variables impact corporate performance. It has also been found that the relationship between corporate governance variables and corporate performance is also dependent upon the type of performance measure selected.

This study has implications for policy makers, academicians and investors since findings indicate impact of specific corporate governance variable on corporate financial performance. The study is important for both domestic and for- 
eign investors as it gives an indication to the type of companies (from corporate governance point of view) in Indian context that may give better financial results. Investors should put in their money in those Indian companies that have controlling stakes held by promoters; as those companies are expected to give better performance. Foreign investors should also look for companies which already have significant stakes of institutional ownership or FII ownership. Findings indicate that investors should look for companies with optimal and diversified board. By implication, it is indicated that if foreign investors in developed economies come with their newer technologies and improved corporate governance practices, it may result into good corporate performance.

The study reiterates the belief that board meeting dynamics impact the corporate governance structure and mechanism. These dynamics and finer threads of board meeting issues are quite hidden from the public domain and are not easily identifiable by researchers and investors. The board decision making process and monitoring for implementation of those decisions could impact corporate governance performance relationship. Thus future studies may incorporate these parameters and highlighted intricate determinants of corporate governance.

This study can further be enhanced in many areas through future research on corporate governance, particularly in the context of emerging economies. One area may be to develop an event study around introduction of major changes in corporate governance regime in India like 2000 (introduction of clause 49 in the listing agreement), 2004 (introduction of penal provisions in clause 49), 2010 (recommendations of Murthy committee on audit committee and whistle blower policy) and 2014 (enforcement of new companies act with specific provisions on corporate governance). This may give insights on impact of specific governance mechanism on corporate performance in Indian context.

Another area of interest for researchers may be corporate governance mechanisms common to emerging economies. Analytical frameworks for the same may be developed. This may help in developing some kind of predictive model for understanding future performance based on present corporate governance practice for emerging economies.

As corporate governance mechanism undergoes redefinition with time future research scope becomes vast and more critical in terms of variables of corporate governance, estimating corporate governance model and the firm performance variables. In future research, any potential interrelationships between corporate governance practices and contextual variables can also be taken into account.

\section{Conflicts of Interest}

The authors declare no conflicts of interest regarding the publication of this paper.

\section{References}

[1] Shleifer, A. and Vishny, R.W. (1997) A Survey of Corporate Governance. The Jour- 
nal of Finance, 52, 737-783. https://doi.org/10.1111/j.1540-6261.1997.tb04820.x

[2] Becht, M., Bolton, P. and Röell, A. (2003) Corporate Governance and Control. Handbook of the Economics of Finance, 1, 1-109. https://doi.org/10.1016/S1574-0102(03)01005-7

[3] Girma, S., Thompson, S. and Wright, P.W. (2007) Corporate Governance Reforms and Executive Compensation Determination: Evidence from the UK. The Manchester School, 75, 65-81. https://doi.org/10.1111/j.1467-9957.2007.01003.x

[4] Chalevas, C. and Tzovas, C. (2010) The Effect of the Mandatory Adoption of Corporate Governance Mechanisms on Earnings Manipulation, Management Effectiveness and Firm Financing: Evidence from Greece. Managerial Finance, 36, 257-277. https://doi.org/10.1108/03074351011019573

[5] Hermalin, B.E. and Weisbach, M.S. (1991) The Effects of Board Composition and Direct Incentives on Firm Performance. Financial Management, 20, 101-112.

[6] Kang, J.K. and Shivdasani, A. (1995) Firm Performance, Corporate Governance, and Top Executive Turnover in Japan. Journal of Financial Economics, 38, 29-58. https://doi.org/10.1016/0304-405X(94)00807-D

[7] Judge, W.Q., Naoumova, I. and Koutzevol, N. (2003) Corporate Governance and Firm Performance in Russia: An Empirical Study. Journal of World Business, 38, 385-396. https://doi.org/10.1016/j.jwb.2003.08.023

[8] Gompers, P., Ishii, J. and Metrick, A. (2003) Corporate Governance and Equity Prices. The Quarterly Journal of Economics, 118, 107-156.

https://doi.org/10.1162/00335530360535162

[9] Pass, C. (2004) Corporate Governance and the Role of Non-Executive Directors in Large UK Companies: An Empirical Study. Corporate Governance: The International Journal of Business in Society, 4, 52-63. https://doi.org/10.1108/14720700410534976

[10] Bauer, R., Guenster, N. and Otten, R. (2004) Empirical Evidence on Corporate Governance in Europe: The Effect on Stock Returns, Firm Value and Performance. Journal of Asset Management, 5, 91-104. https://doi.org/10.1057/palgrave.jam.2240131

[11] Bhagat, S. and Bolton, B. (2008) Corporate Governance and Firm Performance. Journal of Corporate Finance, 14, 257-273. https://doi.org/10.1016/j.jcorpfin.2008.03.006

[12] Fan, J.P., Wei, K.C. and Xu, X. (2011) Corporate Finance and Governance in Emerging Markets: A Selective Review and an Agenda for Future Research. Journal of Corporate Finance, 17, 207-214. https://doi.org/10.1016/j.jcorpfin.2010.12.001

[13] Khanna, T. and Palepu, K. (2000) The Future of Business Groups in Emerging Markets: Long-Run Evidence from Chile. Academy of Management Journal, 43, 268-285.

[14] Khanna, T. and Palepu, K. (2000) Emerging market Business Groups, Foreign Intermediaries, and Corporate Governance. Concentrated Corporate Ownership University of Chicago Press, Chicago, IL, 265-294. https://doi.org/10.3386/w6955

[15] Gibson, M.S. (2003) Is Corporate Governance Ineffective in Emerging Markets? Journal of Financial and Quantitative Analysis, 38, 231-250. https://doi.org/10.2307/4126771

[16] Klapper, L.F. and Love, I. (2004) Corporate Governance, Investor Protection, and Performance in Emerging Markets. Journal of Corporate Finance, 10, 703-728. https://doi.org/10.1016/S0929-1199(03)00046-4 
[17] Young, M.N., Peng, M.W., Ahlstrom, D., Bruton, G.D. and Jiang, Y. (2008) Corporate Governance in Emerging Economies: A Review of the Principal-Principal Perspective. Journal of Management Studies, 45, 196-220. https://doi.org/10.1111/j.1467-6486.2007.00752.x

[18] Ehikioya, B.I. (2009) Corporate Governance Structure and Firm Performance in Developing Economies: Evidence from Nigeria. Corporate Governance, 9, 231-243. https://doi.org/10.1108/14720700910964307

[19] Claessens, S. and Yurtoglu, B.B. (2013) Corporate Governance in Emerging Markets: A Survey. Emerging Markets Review, 15, 1-33. https://doi.org/10.1016/j.ememar.2012.03.002

[20] Rajagopalan, N. and Zhang, Y. (2008) Corporate Governance Reforms in China and India: Challenges and Opportunities. Business Horizons, 51, 55-64. https://doi.org/10.1016/j.bushor.2007.09.005

[21] Jackling, B. and Johl, S. (2009) Board Structure and Firm Performance: Evidence from India's Top Companies. Corporate Governance: An International Review, 17, 492-509. https://doi.org/10.1111/j.1467-8683.2009.00760.x

[22] Varma, J.R. (1997) Corporate Governance in India: Disciplining the Dominant Shareholder. IIMB Management Review, 9, 5-18.

[23] Chakrabarti, R., Megginson, W. and Yadav, P.K. (2008) Corporate Governance in India. Journal of Applied Corporate Finance, 20, 59-72. https://doi.org/10.1111/j.1745-6622.2008.00169.x

[24] Pande, S. and Ansari, V.A. (2013) A Note on the Efficacy of the Current Corporate Governance Regulations in India. https://doi.org/10.2139/ssrn.2333023

[25] Carney, M. and Gedajlovic, E. (2002) The Co-Evolution of Institutional Environments and Organizational Strategies: The Rise of Family Business Groups in the ASEAN Region. Organization Studies, 23, 1-29. https://doi.org/10.1177/0170840602231001

[26] Gomez-Mejia, L.R., Larraza-Kintana, M. and Makri, M. (2003) The Determinants of Executive Compensation in Family-Controlled Public Corporations. Academy of Management Journal, 46, 226-237.

[27] Dennis, D.K. and McConnell, J.J. (2003) International Corporate Governance. Journal of Financial and Quantitative Analysis, 38, 1-36. https://doi.org/10.2307/4126762

[28] Sarkar, J. and Sarkar, S. (2000) Large Shareholder Activism in Corporate Governance in Developing Countries: Evidence from India. International Review of Finance, 1, 161-194. https://doi.org/10.1111/1468-2443.00010

[29] Kumar, J. (2004) Does Corporate Governance Influence Firm Value? Evidence from Indian Firms. The Journal of Entrepreneurial Finance and Business Ventures, 9, 61-92.

[30] Dharmapala, D. and Khanna, V.S. (2008) Corporate Governance, Enforcement, and Firm Value: Evidence from India. University of Michigan Law \& Economics, Ann Arbor, MI.

[31] Balasubramanian, N., Black, B.S. and Khanna, V. (2010) The Relation between Firm-Level Corporate Governance and Market Value: A Case Study of India. Emerging Markets Review, 11, 319-340. https://doi.org/10.1016/j.ememar.2010.05.001

[32] Kota, H.B. and Tomar, S. (2010) Corporate Governance Practices in Indian Firms. Journal of Management and Organization, 16, 266-279. 
https://doi.org/10.1017/S1833367200002170

[33] Kumar, N. and Singh, J.P. (2012) Outside Directors, Corporate Governance and Firm Performance: Empirical Evidence from India. Asian Journal of Finance \& Accounting, 4, 39-55. https://doi.org/10.5296/ajfa.v4i2.1737

[34] Pahuja, A. and Bhatia, B.S. (2010) Determinants of Corporate Governance Disclosures: Evidence from Companies in Northern India. IUP Journal of Corporate Governance, 9, 69-88.

[35] Hart, O. (1995) Corporate Governance: Some Theory and Implications. The Economic Journal, 678-689. https://doi.org/10.2307/2235027

[36] Burkart, M., Gromb, D. and Panunzi, F. (1997) Large Shareholders, Monitoring, and the Value of the Firm. The Quarterly Journal of Economics, 112, 693-728. https://doi.org/10.1162/003355397555325

[37] Holderness, C.G. (2003) A Survey of Blockholders and Corporate Control. Economic Policy Review, 9, 51-64.

[38] Mishra, R.K. and Kapil, S. (2016) Study on Corporate Governance Mechanisms. International Journal of Indian Culture and Business Management, 12, 179-203. https://doi.org/10.1504/IJICBM.2016.074480

[39] Morck, R., Shleifer, A. and Vishny, R.W. (1988) Management Ownership and Market Valuation: An Empirical Analysis. Journal of Financial Economics, 20, 293-315. https://doi.org/10.1016/0304-405X(88)90048-7

[40] Shleifer, A. and Vishny, R.W. (1989) Management Entrenchment: The Case of Manager-Specific Investments. Journal of Financial Economics, 25, 123-139. https://doi.org/10.1016/0304-405X(89)90099-8

[41] Kumar, N. and Singh, J.P. (2013) Effect of Board Size and Promoter Ownership on Firm Value: Some Empirical Findings from India. Corporate Governance: The International Journal of Business in Society, 13, 88-98.

https://doi.org/10.1108/14720701311302431

[42] Ganguli, S.K. (2013) Capital Structure-Does Ownership Structure Matter? Theory and Indian Evidence. Studies in Economics and Finance, 30, 56-72.

https://doi.org/10.1108/10867371311300982

[43] Richter, A. and Chakraborty, I. (2015) Promoter Ownership and Performance in Publicly Listed Firms in India: Does Group Affiliation Matter? Occasional Paper No. 45, Institute of Development Studies Kolkata, Kolkata, West Bengal.

[44] Ohadi, F., Sabetfar, P. and Asgari, Z. (2014) Empirical Test of the Relationship between Debt Leverage and Ownership Structure on Iranian Firms. Asian Journal of Research in Banking and Finance, 4, 179-190. https://doi.org/10.5958/2249-7323.2014.00955.9

[45] Sahu, M. (2013) Rights of Minority Shareholders in India Under the Companies Act, 1956. https://doi.org/10.2139/ssrn.2564925

[46] Kakani, R.K., Saha, B. and Reddy, V.N. (2006) Determinants of Financial Performance of Indian Corporate Sector in the Post-Liberalization Era: An Exploratory Study. SSRN Working Paper Series. https://www.nseindia.com/content/research/Paper18.pdf

[47] Anderson, R.C. and Reeb, D.M. (2003) Founding-Family Ownership and Firm Performance: Evidence from the S \& P 500. The Journal of Finance, 58, 1301-1328. https://doi.org/10.1111/1540-6261.00567

[48] Jensen, M.C. and Meckling, W.H. (1976) Theory of the Firm: Managerial Behavior, Agency Costs and Ownership Structure. Journal of Financial Economics, 3, 
305-360. https://doi.org/10.1016/0304-405X(76)90026-X

[49] McConnell, J.J. and Servaes, H. (1990) Additional Evidence on Equity Ownership and Corporate Value. Journal of Financial Economics, 27, 595-612.

https://doi.org/10.1016/0304-405X(90)90069-C

[50] Oswald, S.L. and Jahera, J.S. (1991) The Influence of Ownership on Performance: An Empirical Study. Strategic Management Journal, 12, 321-326. https://doi.org/10.1002/smj.4250120407

[51] Hudson, C.D., Jahera, J.S. and Lloyd, W.P. (1992) Further Evidence on the Relationship between Ownership and Performance. Financial Review, 27, 227-239. https://doi.org/10.1111/j.1540-6288.1992.tb01315.x

[52] Chung, K.H. and Pruitt, S.W. (1996) Executive Ownership, Corporate Value, and Executive Compensation: A Unifying Framework. Journal of Banking \& Finance, 20, 1135-1159. https://doi.org/10.1016/0378-4266(95)00039-9

[53] Chang, S.J. (2003) Ownership Structure, Expropriation, and Performance of Group-Affiliated Companies in Korea. Academy of Management Journal, 46, 238-253.

[54] Jensen, M.C. and Ruback, R.S. (1983) The Market for Corporate Control: The Scientific Evidence. Journal of Financial Economics, 11, 5-50.

https://doi.org/10.1016/0304-405X(83)90004-1

[55] Fan, J.P. and Wong, T.J. (2002) Corporate Ownership Structure and the Informativeness of Accounting Earnings in East Asia. Journal of Accounting and Economics, 33, 401-425. https://doi.org/10.1016/S0165-4101(02)00047-2

[56] Barnhart, S.W. and Rosenstein, S. (1998) Board Composition, Managerial Ownership, and Firm Performance: An Empirical Analysis. Financial Review, 33, 1-16. https://doi.org/10.1111/j.1540-6288.1998.tb01393.x

[57] Chen, C.R., Guo, W. and Mande, V. (2003) Managerial Ownership and Firm Valuation: Evidence from Japanese Firms. Pacific-Basin Finance Journal, 11, 267-283. https://doi.org/10.1016/S0927-538X(03)00024-6

[58] Pound, J. (1992) Raiders, Targets, and Politics: The History and Future of American Corporate Control. Journal of Applied Corporate Finance, 5, 6-18. https://doi.org/10.1111/j.1745-6622.1992.tb00222.x

[59] Shin-Ping, L. and Tsung-Hsien, C. (2009) The Determinants of Corporate Performance: A Viewpoint from Insider Ownership and Institutional Ownership. Managerial Auditing Journal, 24, 233-247. https://doi.org/10.1108/02686900910941122

[60] Douma, S., George, R. and Kabir, R. (2006) Foreign and Domestic Ownership, Business Groups, and Firm Performance: Evidence from a Large Emerging Market. Strategic Management Journal, 27, 637-657. https://doi.org/10.1002/smj.535

[61] Dossani, R. (2012) Private Equity and Corporate Governance in India. Journal of Asia Business Studies, 6, 223-238. https://doi.org/10.1108/15587891211254416

[62] Hermalin, B.E. and Weisbach, M.S. (2001) Boards of Directors as an Endogenously Determined Institution: A Survey of the Economic Literature. National Bureau of Economic Research. https://doi.org/10.3386/w8161

[63] Shukeri, S.N., Shin, O.W. and Shaari, M.S. (2012) Does Board of Director's Characteristics Affect Firm Performance? Evidence from Malaysian Public Listed Companies. International Business Research, 5, 120-127. https://doi.org/10.5539/ibr.v5n9p120

[64] Fauzi, F. and Locke, S. (2012) Board Structure, Ownership Structure and Firm Performance: A Study of New Zealand Listed-Firms. Asian Academy of Management 
Journal of Accounting of Finance, 8, 43-67. https://doi.org/10.2139/ssrn.2047218

[65] Abor, J. and Biekpe, N. (2007) Corporate Governance, Ownership Structure and Performance of SMEs in Ghana: Implications for Financing Opportunities. Corporate Governance, 7, 288-300. https://doi.org/10.1108/14720700710756562

[66] Sheikh, N.A., Wang, Z. and Khan, S. (2013) The Impact of Internal Attributes of Corporate Governance on Firm Performance: Evidence from Pakistan. International Journal of Commerce and Management, 23, 38-55. https://doi.org/10.1108/10569211311301420

[67] Alves, S.M.G. (2011) The Effect of the Board Structure on Earnings Management: Evidence from Portugal. Journal of Financial Reporting and Accounting, 9, 141-160. https://doi.org/10.1108/19852511111173103

[68] Yermack, D. (1996) Higher Market Valuation of Companies with a Small Board of Directors. Journal of Financial Economics, 40, 185-211. https://doi.org/10.1016/0304-405X(95)00844-5

[69] Eisenberg, T., Sundgren, S. and Wells, M.T. (1998) Larger Board Size and Decreasing Firm Value in Small Firms. Journal of Financial Economics, 48, 35-54. https://doi.org/10.1016/S0304-405X(98)00003-8

[70] Lipton, M. and Lorsch, J.W. (1992) A Modest Proposal for Improved Corporate Governance. The Business Lawyer, 48, 59-77.

[71] Khanchel, I. (2007) Corporate Governance: Measurement and Determinant Analysis. Managerial Auditing Journal, 22, 740-760. https://doi.org/10.1108/02686900710819625

[72] Garg, A.K. (2007) Influence of Board Size and Independence on Firm Performance: A Study of Indian Companies. Vikalpa: The Journal for Decision Makers, 32, 39-60. https://doi.org/10.1177/0256090920070304

[73] Baysinger, B.D. and Butler, H.N. (1985) Corporate Governance and the Board of Directors: Performance Effects of Changes in Board Composition. Journal of Law, Economics, \& Organization, 1, 101-124.

[74] Mak, Y.T. and Kusnadi, Y. (2005) Size Really Matters: Further Evidence on the Negative Relationship between Board Size and Firm Value. Pacific-Basin Finance Journal, 13, 301-318. https://doi.org/10.1016/j.pacfin.2004.09.002

[75] Black, B. and Kim, W. (2012) The Effect of Board Structure on Firm Value: A Multiple Identification Strategies Approach Using Korean Data. Journal of Financial Economics, 104, 203-226. https://doi.org/10.1016/j.jfineco.2011.08.001

[76] Yammeesri, J. and Herath, S.K. (2010) Board Characteristics and Corporate Value: Evidence from Thailand. Corporate Governance, 10, 279-292. https://doi.org/10.1108/14720701011051910

[77] Gill, S. (2013) Rethinking the Primacy of Board Efficacy for Governance: Evidence from India. Corporate Governance, 13, 99-129. https://doi.org/10.1108/14720701311302440

[78] Roberts, J., McNulty, T. and Stiles, P. (2005) Beyond Agency Conceptions of the Work of the Non-Executive Director: Creating Accountability in the Boardroom. British Journal of Management, 16, S5-S26. https://doi.org/10.1111/j.1467-8551.2005.00444.x

[79] Minichilli, A., Zattoni, A. and Zona, F. (2009) Making Boards Effective: An Empirical Examination of Board Task Performance. British Journal of Management, 20, 55-74. https://doi.org/10.1111/j.1467-8551.2008.00591.x

[80] Judge, W.Q. and Zeithaml, C.P. (1992) Institutional and Strategic Choice Perspec- 
tives on Board Involvement in the Strategic Decision Process. Academy of Management Journal, 35, 766-794.

[81] Vafeas, N. (1999) Board Meeting Frequency and Firm Performance. Journal of Financial Economics, 53, 113-142. https://doi.org/10.1016/S0304-405X(99)00018-5

[82] Davis, J.H., Schoorman, F.D. and Donaldson, L. (1997) Toward a Stewardship Theory of Management. Academy of Management Review, 22, 20-47. https://doi.org/10.5465/amr.1997.9707180258

[83] Lam, T.Y. and Lee, S.K. (2008) CEO Duality and Firm Performance: Evidence from Hong Kong. Corporate Governance, 8, 299-316. https://doi.org/10.1108/14720700810879187

[84] Higgs, D. (2003) Review of the Role and Effectiveness of Non-Executive Directors. DtI (Diffusion Tensor Imaging), London, 1-120.

[85] Jensen, M.C. (1993) The Modern Industrial Revolution, Exit, and the Failure of Internal Control Systems. The Journal of Finance, 48, 831-880. https://doi.org/10.1111/j.1540-6261.1993.tb04022.x

[86] Weisbach, M.S. (1988) Outside Directors and CEO Turnover. Journal of Financial Economics, 20, 431-460. https://doi.org/10.1016/0304-405X(88)90053-0

[87] Hassan, M.K. and Halbouni, S.S. (2013) Corporate Governance, Economic Turbulence and Financial Performance of UAE Listed Firms. Studies in Economics and Finance, 30, 118-138. https://doi.org/10.1108/10867371311325435

[88] Collett, N. and Dedman, E. (2010) Large Share Price Movements, the Disclosure of News and Corporate Governance: Implications for Disclosure Rules. Journal of Applied Accounting Research, 11, 109-132. https://doi.org/10.1108/09675421011069496

[89] Forbes, D.P. and Milliken, F.J. (1999) Cognition and Corporate Governance: Understanding Boards of Directors as Strategic Decision-Making Groups. Academy of Management Review, 24, 489-505. https://doi.org/10.5465/amr.1999.2202133

[90] Brown, L.D. and Caylor, M.L. (2004) Corporate Governance and Firm Performance. https://doi.org/10.2139/ssrn.586423

[91] Brick, I.E. and Chidambaran, N.K. (2010) Board Meetings, Committee Structure, and Firm Value. Journal of Corporate Finance, 16, 533-553. https://doi.org/10.1016/j.jcorpfin.2010.06.003

[92] Mishra, S. and Mohanty, P. (2014) Corporate Governance as a Value Driver for Firm Performance: Evidence from India. Corporate Governance, 14, 265-280. https://doi.org/10.1108/CG-12-2012-0089

[93] Fama, E.F. (1980) Agency Problems and the Theory of the Firm. The Journal of Political Economy, 88, 288-307. https://doi.org/10.1086/260866

[94] Fama, E.F. and Jensen, M.C. (1983) Separation of Ownership and Control. Journal of Law and Economics, 26, 301-325. https://doi.org/10.1086/467037

[95] Perry, T. and Peyer, U. (2005) Board Seat Accumulation by Executives: A Shareholder's Perspective. The Journal of Finance, 60, 2083-2123. https://doi.org/10.1111/j.1540-6261.2005.00788.x

[96] Jiraporn, P., Singh, M. and Lee, C.I. (2009) Ineffective Corporate Governance: Director Busyness and Board Committee Memberships. Journal of Banking \& Finance, 33, 819-828. https://doi.org/10.1016/j.jbankfin.2008.09.020

[97] Ferris, S.P., Jagannathan, M. and Pritchard, A.C. (2003) Too Busy to Mind the Business? Monitoring by Directors with Multiple Board Appointments. The Journal of Finance, 58, 1087-1111. https://doi.org/10.1111/1540-6261.00559 
[98] Fich, E.M. and Shivdasani, A. (2006) Are Busy Boards Effective Monitors? The Journal of Finance, 61, 689-724. https://doi.org/10.1111/j.1540-6261.2006.00852.x

[99] Harris, I.C. and Shimizu, K. (2004) Too Busy to Serve? An Examination of the Influence of over Boarded Directors. Journal of Management Studies, 41, 775-798. https://doi.org/10.1111/j.1467-6486.2004.00453.x

[100] Booth, J.R. and Deli, D.N. (1996) Factors Affecting the Number of outside Directorships Held by CEOs. Journal of Financial Economics, 40, 81-104. https://doi.org/10.1016/0304-405X(95)00838-6

[101] Khanna, T. and Rivkin, J.W. (2001) Estimating the Performance Effects of Business Groups in Emerging Markets. Strategic Management Journal, 22, 45-74. https://doi.org/10.1002/1097-0266(200101)22:1<45::AID-SMJ147>3.0.CO;2-F

[102] Black, B.S. and Khanna, V.S. (2007) Can Corporate Governance Reforms Increase Firm Market Values? Event Study Evidence from India. Journal of Empirical Legal Studies, 4, 749-796. https://doi.org/10.1111/j.1740-1461.2007.00106.x

[103] Hermalin, B.E. and Weisbach, M.S. (2012) Information Disclosure and Corporate Governance. The Journal of Finance, 67, 195-233. https://doi.org/10.1111/j.1540-6261.2011.01710.x

[104] Yatim, P., Kent, P. and Clarkson, P. (2006) Governance Structures, Ethnicity, and Audit Fees of Malaysian Listed Firms. Managerial Auditing Journal, 21, 757-782. https://doi.org/10.1108/02686900610680530

[105] Black, B.S., De Carvalho, A.G. and Gorga, E. (2010) Corporate Governance in Brazil. Emerging Markets Review, 11, 21-38. https://doi.org/10.1016/j.ememar.2009.09.004

[106] Mustapha, M. and Ahmad, A.C. (2011) Agency Costs of Debt and Monitoring. International Review of Business Research Papers, 7, 118-129.

[107] Di Vito, J. and Bozec, Y. (2012) Controlling Shareholder Entrenchment, Corporate Governance and Corporate Performance. International Journal of Accounting and Finance, 3, 273-289. https://doi.org/10.1504/IJAF.2012.048503

[108] Agrawal, A. and Knoeber, C.R. (1996) Firm Performance and Mechanisms to Control Agency Problems between Managers and Shareholders. Journal of Financial and Quantitative Analysis, 31, 377-397. https://doi.org/10.2307/2331397

[109] Loderer, C. and Peyer, U. (2002) Board Overlap, Seat Accumulation and Share Prices. European Financial Management, 8, 165-192. https://doi.org/10.1111/1468-036X.00183

[110] Perfect, S.B. and Wiles, K.W. (1994) Alternative Constructions of Tobin's $q$ : An Empirical Comparison. Journal of Empirical Finance, 1, 313-341. https://doi.org/10.1016/0927-5398(94)90007-8

[111] Reddy, K., Locke, S., Scrimgeour, F. and Gunasekarage, A. (2008) Corporate Governance Practices of Small Cap Companies and Their Financial Performance: An Empirical Study in New Zealand. International Journal of Business Governance and Ethics, 4, 51-78. https://doi.org/10.1504/IJBGE.2008.017891

[112] Demsetz, H. and Villalonga, B. (2001) Ownership Structure and Corporate Performance. Journal of Corporate Finance, 7, 209-233. https://doi.org/10.1016/S0929-1199(01)00020-7

[113] Thomsen, S., Pedersen, T. and Kvist, H.K. (2006) Blockholder Ownership: Effects on Firm Value in Market and Control Based Governance Systems. Journal of Corporate Finance, 12, 246-269. https://doi.org/10.1016/j.jcorpfin.2005.03.001

[114] Copeland, Tom, Tim Koller, and Jack Murrin (2000) Valuation: Measuring and 
Managing the Value of Companies. Auflage, New York.

[115] Arora, A. and Sharma, C. (2016) Corporate Governance and Firm Performance in Developing Countries: Evidence from India. Corporate Governance, 16, 420-436. https://doi.org/10.1108/CG-01-2016-0018

[116] Ayuso, S., Rodríguez, M.A., García-Castro, R. and Ariño, M.A. (2014) Maximizing Stakeholders' Interests: An Empirical Analysis of the Stakeholder Approach to Corporate Governance. Business \& Society, 53, 414-439. https://doi.org/10.1177/0007650311433122

[117] Crespi, R. and Renneboog, L. (2010) Is (Institutional) Shareholder Activism New? Evidence from UK Shareholder Coalitions in the Pre-Cadbury Era. Corporate Governance. An International Review, 18, 274-295. https://doi.org/10.1111/j.1467-8683.2010.00795.x

[118] Guest, P.M. (2009) The Impact of Board Size on Firm Performance: Evidence from the UK. The European Journal of Finance, 15, 385-404. https://doi.org/10.1080/13518470802466121

[119] Beiner, S., Drobetz, W., Schmid, F. and Zimmermann, H. (2004) Is Board Size an Independent Corporate Governance Mechanism? Kyklos, 57, 327-356. https://doi.org/10.1111/j.0023-5962.2004.00257.x

[120] Reddy, K., Locke, S. and Scrimgeour, F. (2010) The Efficacy of Principle-Based Corporate Governance Practices and Firm Financial Performance: An Empirical Investigation. International Journal of Managerial Finance, 6, 190-219. https://doi.org/10.1108/17439131011056224

[121] Capron, L., Mitchell, W. and Swaminathan, A. (2001) Asset Divestiture Following Horizontal Acquisitions: A Dynamic View. Strategic Management Journal, 22, 817-844. https://doi.org/10.1002/smj.175

[122] Dwivedi, N. and Jain, A.K. (2005) Corporate Governance and Performance of Indian Firms: The Effect of Board Size and Ownership. Employee Responsibilities and Rights Journal, 17, 161-172. https://doi.org/10.1007/s10672-005-6939-5

[123] Bhaumik, S.K., Driffield, N. and Pal, S. (2010) Does Ownership Structure of Emerging-Market Firms Affect Their outward FDI? The Case of the Indian Automotive and Pharmaceutical Sectors. Journal of International Business Studies, 41, 437-450. https://doi.org/10.1057/jibs.2009.52

[124] Selarka, E. (2005) Ownership Concentration and Firm Value: A Study from the Indian Corporate Sector. Emerging Markets Finance and Trade, 41, 83-108. https://doi.org/10.1080/1540496X.2005.11052627

[125] Ghosh, S. (2006) Do Board Characteristics Affect Corporate Performance? Firm-Level Evidence for India. Applied Economics Letters, 13, 435-443. https://doi.org/10.1080/13504850500398617

[126] Sarkar, J. and Sarkar, S. (2009) Multiple Board Appointments and Firm Performance in Emerging Economies: Evidence from India. Pacific-Basin Finance Journal, 17, 271-293. https://doi.org/10.1016/j.pacfin.2008.02.002 